\title{
A Concise Stereoselective Synthesis of Preussin, 3-epi-Preussin, and
}

\section{Analogs}

\author{
Myra Beaudoin Bertrand and John P. Wolfe*
}

Department of Chemistry, University of Michigan, 930 N. University Avenue, Ann Arbor, Michigan 48109-1055

\section{Supporting Information}

Experimental procedures and characterization data for new compounds in Schemes 2-4 and Tables 1-2 (89 pages).

General: All reactions were carried out under an argon or nitrogen atmosphere in oven- or flame-dried glassware. Palladium acetate and all phosphine ligands were purchased from Strem Chemical Co. and used without further purification. All aryl bromides were obtained from commercial sources (Aldrich Chemical $\mathrm{CO}$ or Acros Chemical $\mathrm{CO}$ ) and were used as obtained. Toluene, ether, and THF were purified using a GlassContour solvent purification system. Ratios of regioisomers and/or diastereomers were determined by either ${ }^{1} \mathrm{H}$ NMR or capillary GC analysis of crude reaction mixtures. Yields refer to isolated yields of compounds estimated to be $\geq 95 \%$ pure as determined by ${ }^{1} \mathrm{H} \mathrm{NMR}$, and either capillary GC (known compounds), combustion analysis (new compounds). The yields reported in the supporting information describe the result of a single experiment, whereas the yields reported in Schemes 2-4, and Tables 1-2 are average yields of two or more experiments. Thus, the yields reported in the supporting information may differ from those shown in Schemes 2-4 and Tables 1-2. 


\section{Synthesis of ( \pm )-Preussin (Scheme 2)}

3-Hydroxytetradec-1-en-5-one (7). A flame-dried flask was cooled under a stream of nitrogen and charged with diisopropylamine $(7.4 \mathrm{~mL}, 52.5 \mathrm{mmol})$ and tetrahydrofuran $(300 \mathrm{~mL})$. The resulting solution was cooled to $-78{ }^{\circ} \mathrm{C}$ and $n$-butyllithium $(20.8 \mathrm{~mL}, 52 \mathrm{mmol}, 2.5 \mathrm{M}$ in hexanes) was added dropwise. The reaction mixture was stirred at $-78{ }^{\circ} \mathrm{C}$ for $30 \mathrm{~min}$ and then a solution of 2-undecanone $(8.52 \mathrm{~g}, 50 \mathrm{mmol})$ in tetrahydrofuran $(30 \mathrm{~mL})$ was added dropwise. The reaction mixture was stirred at $78{ }^{\circ} \mathrm{C}$ for $1 \mathrm{~h}$ then a solution of acrolein $(3.5 \mathrm{~mL}, 52.5 \mathrm{mmol})$ in tetrahydrofuran $(30 \mathrm{~mL})$ was then slowly added dropwise. The resulting mixture was stirred at $-78^{\circ} \mathrm{C}$ for $35 \mathrm{~min}$ and then warmed to rt. Saturated aqueous $\mathrm{NH}_{4} \mathrm{Cl}(25 \mathrm{~mL})$ and diethyl ether $(200 \mathrm{~mL})$ were added, the layers were separated and the aqueous layer was extracted with diethyl ether $(3 \times 150 \mathrm{~mL})$. The combined organic extracts were dried over anhydrous $\mathrm{Na}_{2} \mathrm{SO}_{4}$, filtered, and concentrated in vacuo. The crude product was purified by flash chromatography using $5 \% \rightarrow 10 \%$ ethyl acetate/hexanes as the eluent to afford $8.88 \mathrm{~g}(78 \%)$ of the title compound as a colorless oil. ${ }^{1} \mathrm{H}$ NMR (500 MHz, $\left.\mathrm{CDCl}_{3}\right) \delta 5.89-5.82$ (m, $\left.1 \mathrm{H}\right), 5.32-5.27$ (m, $1 \mathrm{H}), 5.15-5.12(\mathrm{~m}, 1 \mathrm{H}), 4.60-4.55$ (m, $1 \mathrm{H}), 3.06$ (s, br, $1 \mathrm{H}), 2.68-2.59(\mathrm{~m}, 2 \mathrm{H}), 2.45-2.40(\mathrm{~m}$, $2 \mathrm{H}), 1.62-1.49$ (m, $2 \mathrm{H}), 1.33-1.20(\mathrm{~m}, 12 \mathrm{H}), 0.88(\mathrm{t}, J=6.8 \mathrm{~Hz}, 3 \mathrm{H}) ;{ }^{13} \mathrm{C} \mathrm{NMR}\left(125 \mathrm{MHz}, \mathrm{CDCl}_{3}\right)$

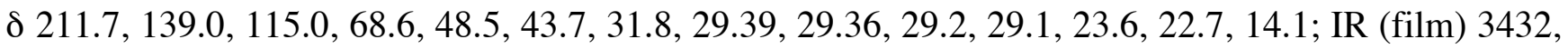
$1710 \mathrm{~cm}^{-1}$. Anal calcd for $\mathrm{C}_{14} \mathrm{H}_{26} \mathrm{O}_{2}$ : C, 74.29; H, 11.58. Found: C, 74.25; H, 11.47.

3-Hydroxytetradec-1-en-5-one- $O$-benzyl oxime (8). A flame-dried flask was cooled under a stream of nitrogen and charged with 7 (11.9 g, $52.6 \mathrm{mmol})$, methanol (190 mL), 0-benzylhydroxylamine (10.1 $\mathrm{g}, 63.2 \mathrm{mmol})$ and pyridine $(11 \mathrm{~mL})$. The resulting mixture was refluxed until the starting material was consumed as judged by TLC analysis (ca. 1h). The mixture was cooled to rt and concentrated in vacuo. The resulting residue was diluted with water $(100 \mathrm{~mL})$ and dichloromethane $(100 \mathrm{~mL})$. The layers were separated and the aqueous layer was extracted with dichloromethane $(3 \mathrm{x} 100 \mathrm{~mL})$. The combined organic extracts were dried over anhydrous $\mathrm{Na}_{2} \mathrm{SO}_{4}$, filtered, and concentrated in vacuo using a rotary evaporator, with trace residual solvent removed under high vacuum for $30 \mathrm{~min}$. The resulting oil was

purified by flash chromatography using $5 \% \rightarrow 10 \%$ ethyl acetate/hexanes as the eluent to afford $16.9 \mathrm{~g}$ (98\%) of the title compound as a colorless oil. This compound was judged to be a 1:1 mixture of oxime isomers as judged by ${ }^{1} \mathrm{H} \mathrm{NMR}$ and ${ }^{13} \mathrm{C} \mathrm{NMR}$. Data are for the mixture. ${ }^{1} \mathrm{H} \mathrm{NMR}\left(500 \mathrm{MHz}, \mathrm{CDCl}_{3}\right)$

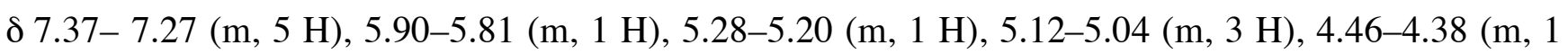
H), 2.71-2.65 (m, 0.5 H), 2.50-2.45 (m, 0.5 H), 2.40-2.28 (m, 2 H), 2.24-2.20 (m, 1 H), 1.54-1.41 (m, 
$2 \mathrm{H}), 1.33-1.19(\mathrm{~m}, 13 \mathrm{H}), 0.88(\mathrm{t}, J=7.1 \mathrm{~Hz}, 3 \mathrm{H}) ;{ }^{13} \mathrm{C}$ NMR (125 MHz, $\left.\mathrm{CDCl}_{3}\right) \delta 160.6,159.2$, $140.3,139.5$, 138.0, 137.6, 128.38, 128.37, 128.14, 128.06, 127.82, 127.79, 114.8, 114.7, 75.7, 75.6, $70.7,69.4,41.0,36.5,35.3,31.9,29.6,29.5,29.48,29.43,29.36,29.31,29.27,29.23,26.3,25.5,22.7$, 14.1 (4 sets of aliphatic carbons are incidentally equivalent); IR (film) $3414,1631 \mathrm{~cm}^{-1}$. Anal calcd for $\mathrm{C}_{21} \mathrm{H}_{33} \mathrm{NO}_{3}$ : C, 76.09; H, 10.03; N, 4.23. Found: C, 75.92; H, 10.02; N, 4.30.

3-Hydroxy-1-nonylpent-4-enylcarbamic acid tert-butyl ester. A flame-dried flask was cooled under a stream of nitrogen and charged with 8 (16.6 g, $50 \mathrm{mmol})$ and diethyl ether $(100 \mathrm{~mL})$. The resulting solution was cooled to $0{ }^{\circ} \mathrm{C}$ and $\mathrm{LiAlH}_{4}(200 \mathrm{~mL}, 200 \mathrm{mmol}, 1 \mathrm{M}$ in diethyl ether) was added dropwise via cannula. The resulting mixture was heated to reflux until the starting material was consumed as judged by TLC analysis (ca. 1h). The reaction mixture was cooled to $0{ }^{\circ} \mathrm{C}$, slowly quenched with water $(30 \mathrm{~mL})$ and diluted with diethyl ether $(100 \mathrm{~mL})$. Aqueous $\mathrm{NaOH}(16 \mathrm{~mL}, 10 \mathrm{M})$ and water $(16 \mathrm{~mL})$ were added sequentially and an insoluble white precipitate formed. The organic supernatant was decanted to a clean Erlenmeyer flask and the precipitate was washed with diethyl ether. The combined organic extracts were dried over anhydrous $\mathrm{Na}_{2} \mathrm{SO}_{4}$ and filtered to afford a solution of 3-hydroxy-1nonylpent-4-enylamine in diethyl ether (ca. $0.1 \mathrm{M}$ ). A portion of this solution was concentrated in vacuo and ${ }^{1} \mathrm{H}$ NMR analysis of this sample indicated that the product was obtained as a 54:46 mixture of syn:anti diastereomers.

A flame-dried flask was cooled under a stream of nitrogen and charged with a solution of 3hydroxy-1-nonylpent-4-enylamine in diethyl ether $(500 \mathrm{~mL}, 50 \mathrm{mmol}, 0.1 \mathrm{M})$. Di-tert-butyl dicarbonate $(16.4 \mathrm{~g}, 75 \mathrm{mmol})$ was added to the solution and the resulting mixture was stirred until the starting material was consumed as judged by TLC analysis (ca. 2h). Aqueous NaOH (200 mL, $1 \mathrm{M}$ ) was added and the resulting biphasic mixture was vigorously stirred for $8 \mathrm{~h}$. The layers were separated and the aqueous layer was extracted with diethyl ether $(3 \times 150 \mathrm{~mL})$. The combined organic extracts were dried over anhydrous $\mathrm{Na}_{2} \mathrm{SO}_{4}$, filtered, and concentrated in vacuo. The crude product was purified by flash chromatography using $10 \% \rightarrow 20 \%$ ethyl acetate/hexanes as the eluent to afford $6.31 \mathrm{~g}(39 \%)$ of $\mathbf{9}$ and $7.62 \mathrm{~g}(46 \%)$ of $\mathbf{1 0}$ as colorless oils.

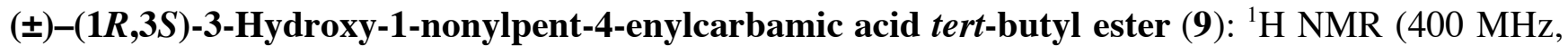
$\left.\mathrm{CDCl}_{3}\right) \delta$ 5.89-5.81 (m, $\left.1 \mathrm{H}\right), 5.27-5.22(\mathrm{~m}, 1 \mathrm{H})$, 5.06-5.02 (m, 1 H), 4.56-4.46 (m, $\left.1 \mathrm{H}\right), 4.18-4.08$ $(\mathrm{m}, 2 \mathrm{H}), 3.81-3.69(\mathrm{~m}, 1 \mathrm{H}), 1.61-1.53(\mathrm{~m}, 1 \mathrm{H}), 1.50-1.16(\mathrm{~m}, 26 \mathrm{H}), 0.88(\mathrm{t}, J=6.3 \mathrm{~Hz}, 3 \mathrm{H}) ;{ }^{13} \mathrm{C}$ NMR $\left(100 \mathrm{MHz}, \mathrm{CDCl}_{3}\right) \delta$ 157.2, 140.3, 113.6, 79.8, 68.4, 47.4, 44.2, 35.6, 31.8, 29.45, 29.43, 29.3, 
29.2, 28.3, 26.1, 22.6, 14.0; IR (film) 3342, $1690 \mathrm{~cm}^{-1}$. Anal calcd for $\mathrm{C}_{19} \mathrm{H}_{37} \mathrm{NO}_{3}: \mathrm{C}, 69.68 ; \mathrm{H}, 11.39$; N, 4.28. Found: C, 69.84; H, 11.46; N, 4.34.

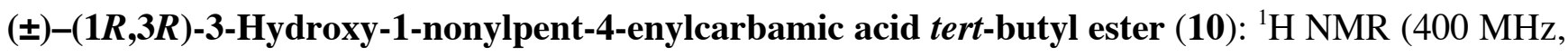
$\left.\mathrm{CDCl}_{3}\right) \delta$ 5.90-5.81 (m, $\left.1 \mathrm{H}\right), 5.25-5.20(\mathrm{~m}, 1 \mathrm{H}), 5.08-5.05(\mathrm{~m}, 1 \mathrm{H}), 4.58-4.44(\mathrm{~m}, 1 \mathrm{H}), 4.23-4.14$ $(\mathrm{m}, 1 \mathrm{H}), 3.72-3.54(\mathrm{~m}, 1 \mathrm{H}), 3.06-2.90(\mathrm{~m}, 1 \mathrm{H}), 1.72-1.53(\mathrm{~m}, 2 \mathrm{H}), 1.52-1.14(\mathrm{~m}, 25 \mathrm{H}), 0.85(\mathrm{t}, J=$ $6.6 \mathrm{~Hz}, 3 \mathrm{H}) ;{ }^{13} \mathrm{C} \mathrm{NMR}\left(100 \mathrm{MHz}, \mathrm{CDCl}_{3}\right) \delta 155.9,140.9,114.3,79.2,70.9,48.3,43.1,36.0,31.8$, 29.51, 29.46, 29.42, 29.2, 28.4, 25.7, 22.6, 14.0; IR (film) 3333, $1682 \mathrm{~cm}^{-1}$. Anal calcd for $\mathrm{C}_{19} \mathrm{H}_{37} \mathrm{NO}_{3}$ : C, 69.68; H, 11.39; N, 4.28. Found: C, 69.79; H, 11.54; N, 4.31.

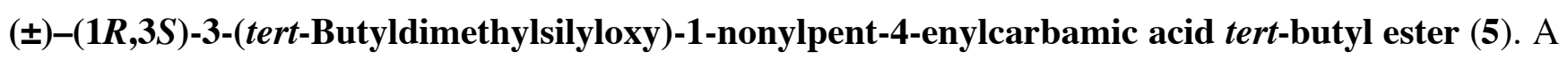
flame-dried flask was cooled under a steam of nitrogen and charged with 9 (6.0 g, $18.3 \mathrm{mmol})$, dimethylformamide (36 mL), imidazole $(2.50 \mathrm{~g}, 36.6 \mathrm{mmol})$ and TBS-Cl (4.42 g, $29.3 \mathrm{mmol})$. The resulting mixture was stirred at $\mathrm{rt}$ until the starting material was consumed as judged by TLC analysis (ca. $24 \mathrm{~h})$. The reaction mixture was diluted with water $(50 \mathrm{~mL})$ and ethyl acetate $(50 \mathrm{~mL})$. The layers were separated and the aqueous layer was extracted with ethyl acetate $(3 \times 50 \mathrm{~mL})$. The combined organic layers were dried over anhydrous $\mathrm{Na}_{2} \mathrm{SO}_{4}$, filtered, and concentrated in vacuo using a rotary evaporator, with trace residual solvent removed under high vacuum for $30 \mathrm{~min}$. The crude product was purified by flash chromatography using 5\% ethyl acetate/hexanes as the eluent to afford $7.6 \mathrm{~g}(94 \%)$ of the title compound as a white solid, m.p. $64-66{ }^{\circ} \mathrm{C} .{ }^{1} \mathrm{H}$ NMR $\left(400 \mathrm{MHz}, \mathrm{CDCl}_{3}\right) \delta 5.84-5.75(\mathrm{~m}, 1 \mathrm{H})$, 5.17-5.11 (m, $1 \mathrm{H})$, 5.05-5.01 (m, $1 \mathrm{H}), 4.93$ (s, br, $1 \mathrm{H}), 4.30-4.22$ (m, 1 H), 3.69-3.54 (m, $1 \mathrm{H})$, 1.74-1.62 (m, 1 H), 1.54-1.36 (m, $12 \mathrm{H}), 1.34-1.15$ (m, $14 \mathrm{H}), 0.94-0.83$ (m, $12 \mathrm{H}), 0.10-0.01$ (m, 6 $\mathrm{H}) ;{ }^{13} \mathrm{C}$ NMR $\left(100 \mathrm{MHz}, \mathrm{CDCl}_{3}\right) \delta$ 155.4, 141.4, 114.1, 78.4, 71.8, 48.1, 42.0, 35.5, 31.9, 29.58, 29.55, $29.50,29.3,28.4,25.9,25.8,22.6,18.0,14.1,-4.1,-5.1$; IR (film) 3339, $1677 \mathrm{~cm}^{-1}$. Anal calcd for $\mathrm{C}_{25} \mathrm{H}_{51} \mathrm{NO}_{3} \mathrm{Si}: \mathrm{C}, 67.97$; H, 11.64; N, 3.17. Found: C, 68.09; H, 11.76; N, 3.18.

( \pm -(2S,3S,5R)-2-Benzyl-3-(tert-butyldimethylsilyloxy)-5-nonylpyrrolidine-1-carboxylic acid tertbutyl ester (11). ${ }^{1}$ A flame-dried Schlenk tube equipped with a magnetic stirbar was cooled under a stream of nitrogen and charged with 5 (111 mg, $0.25 \mathrm{mmol}), \mathrm{Pd}(\mathrm{OAc})_{2}(1.2 \mathrm{mg}, 0.005 \mathrm{mmol}, 2 \mathrm{~mol}$ $\%$ ), dpe-phos (5.4 mg, $0.01 \mathrm{mmol}, 4 \mathrm{~mol} \%), \mathrm{NaO} t \mathrm{Bu}(56 \mathrm{mg}, 0.575 \mathrm{mmol})$ and bromobenzene $(32 \mu \mathrm{L}$, $0.3 \mathrm{mmol})$. The tube was purged with nitrogen and toluene was added using a syringe $(1 \mathrm{~mL})$. The 
resulting mixture was heated to $90{ }^{\circ} \mathrm{C}$ with stirring for 5 hours until the starting material had been consumed as determined by GC analysis. The reaction mixture was cooled to room temperature and saturated aqueous $\mathrm{NH}_{4} \mathrm{Cl}(1 \mathrm{~mL})$ and ethyl acetate $(1 \mathrm{~mL})$ were added. The layers were separated, the aqueous layer was extracted with ethyl acetate $(3 \times 5 \mathrm{~mL})$, and the combined organic layers were dried over $\mathrm{Na}_{2} \mathrm{SO}_{4}$, filtered, and concentrated in vacuo. The crude product was then purified by flash chromatography using $2.5 \%$ ethyl/hexanes as the eluent to afford $85.4 \mathrm{mg}(66 \%)$ of the title compound as a colorless oil. This compound was found to exist as a 3:1 mixture of rotamers as judged by ${ }^{1} \mathrm{H}$ NMR analysis; data are for the mixture. ${ }^{1} \mathrm{H}$ NMR (400 $\left.\mathrm{MHz}, \mathrm{CDCl}_{3}\right) \delta$ 7.35-7.13 (m, $\left.5 \mathrm{H}\right), 4.34-4.22$ (m, 1.25 H), 4.12-3.97 (m, 0.75 H), 3.74-3.50 (m, 1 H), 3.09-2.98 (m, 1 H), 2.88-2.73 (m, 0.25 H), 2.64-2.49 (m, 0.75 H), 2.36-2.13 (m, 1.75 H), 2.07-1.92 (m, 0.25 H), 1.74-1.58 (m, 1 H), 1.50-1.06 $(\mathrm{m}, 24 \mathrm{H}), 1.00-0.84(\mathrm{~m}, 12 \mathrm{H}), 0.17--0.08(\mathrm{~m}, 6 \mathrm{H}) ;{ }^{13} \mathrm{C} \mathrm{NMR}\left(100 \mathrm{MHz}, \mathrm{CDCl}_{3}\right) \delta 154.9,140.0$, 129.8, 128.0, 125.6, 78.9, 71.3, 62.3, 55.6, 37.9, 37.2, 35.9, 31.9, 29.6, 29.5, 29.3, 28.0, 26.5, 25.8, $22.7,18.1,14.1,-4.8,-5.0$.

(士)-Preussin (1). ${ }^{2}$ A flame-dried flask was cooled under a steam of nitrogen and charged with 11 (200 $\mathrm{mg}, 0.39 \mathrm{mmol})$ and tetrahydrofuran $(5 \mathrm{~mL})$. The resulting solution was cooled to $0{ }^{\circ} \mathrm{C}$ and $\mathrm{LiAlH}_{4}(2.4$ $\mathrm{mL}, 2.4 \mathrm{mmol}, 1 \mathrm{M}$ in tetrahydrofuran) was added dropwise via syringe. The resulting mixture was refluxed until the starting material was consumed as judged by TLC analysis (ca. 13h). The reaction mixture was cooled to $0{ }^{\circ} \mathrm{C}$, slowly quenched with water $(1 \mathrm{~mL})$ and diluted with diethyl ether $(5 \mathrm{~mL})$. Aqueous $\mathrm{NaOH}(1 \mathrm{~mL}, 10 \mathrm{M})$ and water $(1 \mathrm{~mL})$ were added sequentially and an insoluble white precipitate formed. The organic supernatant was decanted to a clean Erlenmeyer flask and the precipitate was washed with diethyl ether. The combined organic extracts were dried over anhydrous $\mathrm{Na}_{2} \mathrm{SO}_{4}$, filtered, and concentrated in vacuo. The crude oil obtained was purified by flash chromatography using $10 \%$ methanol/dichloromethane as the eluent to afford $106.2 \mathrm{mg}(85 \%)$ of the title compound as a colorless oil. ${ }^{1} \mathrm{H}$ NMR (400 MHz, $\left.\mathrm{CDCl}_{3}\right) \delta$ 7.29-7.21 (m, $\left.4 \mathrm{H}\right), 7.20-7.12$ (m, 1 H), 3.80-3.69 (m, $1 \mathrm{H})$, 2.90-2.76 (m, $2 \mathrm{H}), 2.29$ (s, $3 \mathrm{H}), 2.26-2.19$ (m, $1 \mathrm{H}), 2.18-2.11(\mathrm{~m}, 1 \mathrm{H})$, 2.10-2.02 (m, $1 \mathrm{H}), 1.74-1.62$ (m, $1 \mathrm{H}), 1.41-1.34$ (m, $1 \mathrm{H}), 1.33-1.13(\mathrm{~m}, 16 \mathrm{H}), 0.85$ (t, $J=7.0 \mathrm{~Hz}, 3$ $\mathrm{H}) ;{ }^{13} \mathrm{C} \mathrm{NMR}\left(100 \mathrm{MHz}, \mathrm{CDCl}_{3}\right) \delta 139.5,129.3,128.3,126.0,73.6,70.3,65.8,39.4,38.6,34.9,33.6$, $31.9,29.9,29.6,29.5,29.3,26.3,22.7,14.1$ 


\section{Synthesis of ( \pm )-3-epi-Preussin (Scheme 3)}

( \pm$)-(1 R, 3 R)-3-($ tert-Butyldimethylsilyloxy)-1-nonylpent-4-enylcarbamic acid tert-butyl ester (12). Syn amino-alcohol derivative 10 (3.27 g, $10 \mathrm{mmol})$ was converted to the title compound (4.0 g, $91 \%$

yield) using a procedure analogous to that employed for the conversion of 9 to 5 . ${ }^{1} \mathrm{H} \mathrm{NMR}(400 \mathrm{MHz}$, $\left.\mathrm{CDCl}_{3}\right) \delta 5.85-5.77(\mathrm{~m}, 1 \mathrm{H}), 5.18-5.14(\mathrm{~m}, 1 \mathrm{H}), 5.05-5.01(\mathrm{~m}, 1 \mathrm{H}), 4.51-4.41(\mathrm{~m}, 1 \mathrm{H}), 4.20-4.10$ $(\mathrm{m}, 1 \mathrm{H}), 3.60-3.46(\mathrm{~m}, 1 \mathrm{H}), 1.63-1.53(\mathrm{~m}, 2 \mathrm{H}), 1.40-1.32(\mathrm{~m}, 11 \mathrm{H}), 1.31-1.18(\mathrm{~m}, 14 \mathrm{H})$, 0.95-0.79 (m, $12 \mathrm{H}), 0.02(\mathrm{~d}, J=9.2 \mathrm{~Hz}, 6 \mathrm{H}) ;{ }^{13} \mathrm{C}$ NMR $\left(100 \mathrm{MHz}, \mathrm{CDCl}_{3}\right) \delta 155.3,141.1,114.4$, 78.6, 72.1, 48.2 , 44.0, 36.0, 31.9, 29.56, 29.51, 29.49, 29.3, 28.4, 25.9, 25.7, 22.6, 18.1, 14.1, -4.3, -4.9; IR (film) 3362, $1703 \mathrm{~cm}^{-1}$. Anal calcd for $\mathrm{C}_{25} \mathrm{H}_{51} \mathrm{NO}_{3} \mathrm{Si}$ : C, 67.97; H, 11.64; N, 3.17. Found: C, 68.07; H, 11.79; N, 3.20.

( \pm -(2S,3R,5R)-2-Benzyl-3-(tert-butyldimethylsilyloxy)-5-nonylpyrrolidine-1-carboxylic acid tertbutyl ester (13). Silyl ether $12(111 \mathrm{mg}, 0.25 \mathrm{mmol})$ was converted to the title compound using a procedure analogous to that employed for the conversion of $\mathbf{5}$ to $\mathbf{1 1}$ to afford $71.6 \mathrm{mg}(55 \%)$ of the title compound as a colorless oil. This compound was found to exist as a 2:1 mixture of rotamers as judged by ${ }^{1} \mathrm{H}$ NMR analysis; data are for the mixture. ${ }^{1} \mathrm{H}$ NMR $\left(400 \mathrm{MHz}, \mathrm{CDCl}_{3}\right) \delta 7.35-7.12(\mathrm{~m}, 5 \mathrm{H})$, 4.02-3.77 (m, 3 H), 3.09-3.01 (m, 0.3 H), 2.93-2.83 (m, 0.7 H), 2.44-2.36 (m, 1 H), 2.18-2.08 (m, 0.6 H), 2.03-1.91 (m, 1.4 H), 1.78-1.69 (m, 1 H), 1.51-1.38 (m, 9 H), 1.35-1.14 (m, $15 \mathrm{H}), 0.88(\mathrm{t}, J=7.0$ $\mathrm{Hz}, 3 \mathrm{H}), 0.75(\mathrm{~s}, 9 \mathrm{H}),-0.20--0.28(\mathrm{~m}, 6 \mathrm{H}) ;{ }^{13} \mathrm{C} \mathrm{NMR}\left(100 \mathrm{MHz}, \mathrm{CDCl}_{3}\right) \delta 155.3,138.7,129.3$, 128.3, 126.2, 78.8, 73.2, 72.2, 69.7, 69.1, 57.2, 40.5, 39.7, 39.3, 38.9, 36.0, 31.9, 29.7, 29.5, 29.4, 29.3, 28.4, 26.1, 25.8, 25.6, 22.6, 17.7, 14.1, -5.18, -5.23. IR (film) $1697 \mathrm{~cm}^{-1}$. Anal calcd for $\mathrm{C}_{31} \mathrm{H}_{55} \mathrm{NO}_{3} \mathrm{Si}_{\text {: }}$ C, 71.90; H, 10.70; N, 2.70. Found: C, 72.15; H, 10.75; N, 2.78.

(士)-3-epi-Preussin (14). ${ }^{3}$ Protected pyrrolidine 13 (200 mg, $0.39 \mathrm{mmol}$ ) was converted to the title compound using a procedure analogous to that employed for the conversion of $\mathbf{1 1}$ to $\mathbf{1}$ to afford $105 \mathrm{mg}$ $(86 \%)$ of a colorless oil. ${ }^{1} \mathrm{H}$ NMR $\left(400 \mathrm{MHz} \mathrm{CDCl}_{3}\right) \delta 7.33-7.17$ (m, $\left.5 \mathrm{H}\right), 4.02-3.95$ (m, $\left.1 \mathrm{H}\right)$, 3.08-3.00 (m, $1 \mathrm{H}), 2.59-2.50(\mathrm{~m}, 1 \mathrm{H}), 2.49-2.38(\mathrm{~m}, 2 \mathrm{H}), 2.35(\mathrm{~s}, 3 \mathrm{H}), 1.79-1.71(\mathrm{~m}, 1 \mathrm{H})$, 1.70-1.59 (m, $2 \mathrm{H}), 1.35-1.09(\mathrm{~m}, 16 \mathrm{H}), 0.87(\mathrm{t}, J=7.0 \mathrm{~Hz}, 3 \mathrm{H}) ;{ }^{13} \mathrm{C} \mathrm{NMR}\left(100 \mathrm{MHz}, \mathrm{CDCl}_{3}\right)$ $\delta 138.9,129.3,128.6,126.4,77.3,74.7,64.9,39.4,39.14,39.05,33.8,31.9,30.0,29.6,29.5,29.3$, $26.4,22.7,14.1$. 


\section{Asymmetric Synthesis of (+)-Preussin (Scheme 4)}

(-)-(R)-N-Decylidene-2-methylpropanesulfinamide (15). A flame-dried flask was cooled under a stream of nitrogen and charged with decanal $(1.7 \mathrm{~mL}, 9.1 \mathrm{mmol})$, titanium ethoxide $(3.5 \mathrm{~mL}, 16.5$ $\mathrm{mmol})$ and tetrahydrofuran $(33 \mathrm{~mL})$. Solid $(R)$-tert-butanesulfinamide $(1.0 \mathrm{~g}, 8.25 \mathrm{mmol})$ was added in one portion and the mixture was stirred at $\mathrm{rt}$ for $3 \mathrm{~h}$. The reaction mixture was poured into a vigorously stirred solution of saturated aqueous $\mathrm{NaCl}(33 \mathrm{~mL})$, the mixture was filtered through celite, and the celite was washed with ethyl acetate $(100 \mathrm{~mL})$. The aqueous phase was extracted with ethyl acetate $(3$ x $30 \mathrm{~mL}$ ) and the combined organic extracts were dried over anhydrous $\mathrm{Na}_{2} \mathrm{SO}_{4}$, filtered, and concentrated in vacuo. The crude material was purified by flash chromatography on silica gel to afford $1.91 \mathrm{~g}(90 \%)$ of the title compound as a colorless oil: $[\alpha]^{23}{ }_{\mathrm{D}}-212.7^{\circ}\left(c\right.$ 1.0, $\left.\mathrm{CHCl}_{3}\right) ;{ }^{1} \mathrm{H}$ NMR $(500$ $\left.\mathrm{MHz}_{\mathrm{CDCl}}\right) \delta 8.06(\mathrm{t}, J=5.0 \mathrm{~Hz}, 1 \mathrm{H}), 2.53-2.49(\mathrm{~m}, 2 \mathrm{H}), 1.62(\mathrm{p}, J=8.0 \mathrm{~Hz}, 2 \mathrm{H}), 1.39-1.20(\mathrm{~m}$, $12 \mathrm{H}), 1.19$ (s, $9 \mathrm{H}), 0.88$ (t, $J=7.0 \mathrm{~Hz}, 3 \mathrm{H}) ;{ }^{13} \mathrm{C} \mathrm{NMR}\left(125 \mathrm{MHz}, \mathrm{CDCl}_{3}\right) \delta$ 169.8, 56.4, 36.1, 31.8, 29.4, 29.3, 29.20, 29.18, 25.5, 22.6, 22.3, 14.1; IR (neat, $\mathrm{cm}^{-1}$ ) 1623. Anal calcd for $\mathrm{C}_{14} \mathrm{H}_{29} \mathrm{NOS}$ : C, 64.81; H, 11.27; N, 5.40. Found: C, 64.93; H, 11.33; N, 5.36.

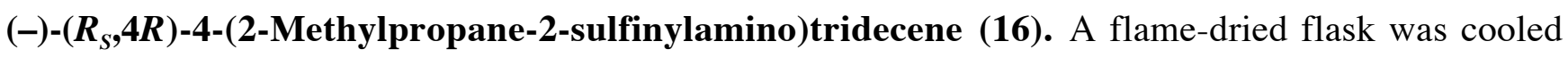
under a stream of nitrogen and charged with $(-)-(R)$-N-decylidene-2-methylpropanesulfinamide $(900$ $\mathrm{mg}, 3.47 \mathrm{mmol})$ and dichloromethane $(35 \mathrm{~mL})$. The flask was cooled to $0{ }^{\circ} \mathrm{C}$ and a solution of allylmagnesium bromide $(5.2 \mathrm{~mL}, 5.2 \mathrm{mmol}, 1.0 \mathrm{M}$ in diethyl ether) was added slowly dropwise. The mixture was stirred at $0{ }^{\circ} \mathrm{C}$ for $30 \mathrm{~min}$ then a solution of saturated aqueous ammonium chloride (20 $\mathrm{mL}$ ) was added. The mixture was warmed to $\mathrm{rt}$, the layers were separated, and the aqueous layer was extracted with ethyl acetate $(3 \times 20 \mathrm{~mL})$. The combined organic layers were dried over anhydrous sodium sulfate, filtered, and concentrated in vacuo. Analysis of the crude product by ${ }^{1} \mathrm{H}$ NMR indicated that a 10:1 mixture of diastereomers had formed. The crude material was purified by flash chromatography on silica gel to afford $824 \mathrm{mg}$ (79\%) of the title compound (a colorless oil) as a single pure diastereomer: $[\alpha]^{23}-53.0^{\circ}\left(c 1.0, \mathrm{CHCl}_{3}\right) ;{ }^{1} \mathrm{H}$ NMR $\left(500 \mathrm{MHz}, \mathrm{CDCl}_{3}\right) \delta 5.83-5.73(\mathrm{~m}, 1 \mathrm{H})$, $5.14(\mathrm{~d}, J=15.0 \mathrm{~Hz}, 2 \mathrm{H}), 3.34-3.26(\mathrm{~m}, 1 \mathrm{H}), 3.19$ (d, $J=7.5 \mathrm{~Hz}, 1 \mathrm{H}), 2.44-2.39$ (m, $1 \mathrm{H}), 2.33-2.27$ $(\mathrm{m}, 1 \mathrm{H}), 1.51-1.45(\mathrm{~m}, 2 \mathrm{H}), 1.36-1.22(\mathrm{~m}, 14 \mathrm{H}), 1.20(\mathrm{~s}, 9 \mathrm{H}), 0.88(\mathrm{t}, J=8.5 \mathrm{~Hz}, 3 \mathrm{H}) ;{ }^{13} \mathrm{C} \mathrm{NMR}$ $\left(125 \mathrm{MHz}, \mathrm{CDCl}_{3}\right) \delta 134.2,118.8,55.7,54.8,40.4,34.9,31.8,29.50,29.48,29.4,29.2,25.4,22.6$, 14.1; IR (neat, $\mathrm{cm}^{-1}$ ) 3216, 1640. Anal calcd for $\mathrm{C}_{17} \mathrm{H}_{35} \mathrm{NOS}: \mathrm{C}, 67.72 ; \mathrm{H}, 11.70 ; \mathrm{N}, 4.65$. Found: $\mathrm{C}$, $67.43 ; \mathrm{H}, 11.82 ; \mathrm{N}, 4.62$. 
(+)-(1R)-1-Nonylpent-4-enylcarbamic acid tert-butyl ester (17). A round-bottom flask was charged with (-)-( $\left.R_{S}, 4 R\right)-4-(2-m e t h y l p r o p a n e-2-s u l f i n y l a m i n o) t r i d e c e n e ~(1.25 \mathrm{~g}, 4.15 \mathrm{mmol})$ and methanol (5 $\mathrm{mL})$. A solution of anhydrous hydrochloric acid (5 mL, $10 \mathrm{mmol}, 2 \mathrm{M}$ in diethyl ether) was added and the mixture was stirred at $\mathrm{rt}$ for $30 \mathrm{~min}$, at which time TLC analysis indicated that the starting material had been completely consumed. The mixture was concentrated in vacuo, and the resulting material was dissolved in a mixture of dioxane $(15 \mathrm{~mL})$, water $(5 \mathrm{~mL})$, and $1 \mathrm{M}$ aqueous $\mathrm{NaOH}(16 \mathrm{~mL}, 16 \mathrm{mmol})$. Solid di-tert-butyldicarbonate was added in one portion and the reaction mixture was stirred at rt for 2 $\mathrm{h}$, at which time TLC analysis indicated the primary amine intermediate had been completely consumed. Tetrahydrofuran $(7 \mathrm{~mL})$ and additional $1 \mathrm{M} \mathrm{NaOH}(7 \mathrm{~mL})$ were added and the resulting mixture was stirred at $\mathrm{rt}$ for $12 \mathrm{~h}$. The reaction mixture was then extracted with ether $(3 \mathrm{x} 40 \mathrm{~mL})$ and the combined organic extracts were dried over anhydrous $\mathrm{Na}_{2} \mathrm{SO}_{4}$, filtered, and concentrated in vacuo. The crude product was purified by flash chromatography on silica gel to afford the title compound $(1.10 \mathrm{~g}, 89 \%)$ as a white solid, m.p. $41-42^{\circ} \mathrm{C}:[\alpha]_{\mathrm{D}}^{23}+19.7^{\circ}\left(c\right.$ 1.0, $\left.\mathrm{CHCl}_{3}\right) ;{ }^{1} \mathrm{H} \mathrm{NMR}(500 \mathrm{MHz}$, $\left.\mathrm{CDCl}_{3}\right) \delta$ 5.80-5.74 (m, $\left.1 \mathrm{H}\right)$, 5.09-5.05 (m, $\left.2 \mathrm{H}\right), 4.34-4.28$ (m, br, $\left.1 \mathrm{H}\right), 3.62$ (s, br, $\left.1 \mathrm{H}\right), 2.28-2.12$ $(\mathrm{m}, 2 \mathrm{H}), 1.43(\mathrm{~s}, 9 \mathrm{H}), 1.33-1.25(\mathrm{~m}, 16 \mathrm{H}), 0.88(\mathrm{t}, J=6.5 \mathrm{~Hz}, 3 \mathrm{H}) ;{ }^{13} \mathrm{C} \mathrm{NMR}\left(125 \mathrm{MHz}, \mathrm{CDCl}_{3}\right)$

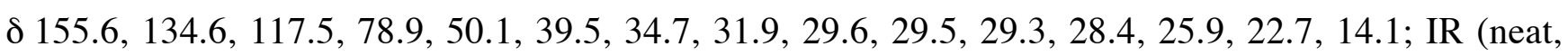
$\mathrm{cm}^{-1}$ ) 3345, 1690. Anal calcd for $\mathrm{C}_{17} \mathrm{H}_{35} \mathrm{NO}_{2}$ : C, 72.68; H, 11.86; N, 4.71. Found: C, 72.91; H, 11.92; $\mathrm{N}, 4.75$.

(+)-(1R)-1-(2-Oxoethyl)decylcarbamic acid tert-butyl ester (18). A round-bottom flask was charged with (+)-(1R)-1-nonylpent-4-enylcarbamic acid tert-butyl ester (594 mg, $2.0 \mathrm{mmol})$ and dichloromethane $(80 \mathrm{~mL})$. The solution was cooled to $-78^{\circ} \mathrm{C}$ and ozone was bubbled through the mixture until a blue color persisted. Dry nitrogen was then bubbled through the solution until the blue color dissipated. Solid triphenylphosphine $(1.05 \mathrm{~g}, 4.0 \mathrm{mmol})$ was added in one portion and the flask was warmed to $\mathrm{rt}$ and stirred for $2 \mathrm{~h}$. The reaction mixture was then concentrated in vacuo and the crude material was purified by flash chromatography on silica gel to afford the title compound (381 $\mathrm{mg}$, $63 \%)$ as a colorless oil: $[\alpha]^{23}+30.8^{\circ}\left(c 1.0, \mathrm{CHCl}_{3}\right) ;{ }^{1} \mathrm{H} \mathrm{NMR}\left(500 \mathrm{MHz}, \mathrm{CDCl}_{3}\right) \delta 9.70(\mathrm{t}, J=2.5 \mathrm{~Hz}$, $1 \mathrm{H}), 4.71(\mathrm{~d}, J=9.0 \mathrm{~Hz}, 1 \mathrm{H}), 4.00-3.93$ (m, $1 \mathrm{H}), 2.60-2.46$ (m, $2 \mathrm{H}), 1.48-1.43$ (m, $2 \mathrm{H}), 1.37$ (s, 9 $\mathrm{H}), 1.26-1.20(\mathrm{~m}, 14 \mathrm{H}), 0.82(\mathrm{t}, J=7.0 \mathrm{~Hz}, 3 \mathrm{H}) ;{ }^{13} \mathrm{C} \mathrm{NMR}\left(125 \mathrm{MHz}, \mathrm{CDCl}_{3}\right) \delta 201.1,155.3,79.3$, 
49.1, 46.4, 35.0, 31.8, 29.4, 29.20, 29.16, 28.4, 25.9, 22.5, 14.0; IR (neat, $\mathrm{cm}^{-1}$ ) 3343, 1716; MS (ESI): 322.2352 (322.2358 calculated for $\mathrm{C}_{17} \mathrm{H}_{33} \mathrm{NO}_{3}, \mathrm{M}+\mathrm{Na}^{+}$).

(+)-(1R,3S)-3-Hydroxy-1-nonylpent-4-enylcarbamic acid tert-butyl ester (9). A flame-dried flask was charged with $\mathrm{CuBr}_{2} \bullet \mathrm{Me}_{2} \mathrm{~S}(1.30 \mathrm{~g}, 6.3 \mathrm{mmol})$ and ether $(23 \mathrm{~mL})$. The resulting suspension was cooled to $-20{ }^{\circ} \mathrm{C}$ and vinyllithium ${ }^{4}(12.6 \mathrm{~mL}, 12.6 \mathrm{mmol}, 1.0 \mathrm{M}$ in ether) was added dropwise. The resulting dark-colored solution was cooled to $-78{ }^{\circ} \mathrm{C}$ and a solution of (+)-(1R)-1-(2oxoethyl)decylcarbamic acid tert-butyl ester $(381 \mathrm{mg}, 1.26 \mathrm{mmol})$ in ether $(4 \mathrm{~mL})$ was added dropwise. The resulting mixture was stirred at $-78{ }^{\circ} \mathrm{C}$ for $2 \mathrm{~h}$ then methanol $(4 \mathrm{~mL})$ was added and the mixture was warmed to rt. Saturated aqueous ammonium chloride $(30 \mathrm{~mL})$ was added, the layers were separated, and the aqueous layer was extracted with ether $(3 \times 30 \mathrm{~mL})$. The combined organic layers were dried over anhydrous $\mathrm{Na}_{2} \mathrm{SO}_{4}$, filtered and concentrated in vacuo. Analysis of the crude material by ${ }^{1} \mathrm{H}$ NMR revealed that the product had been formed as a 3:1 mixture of diastereomers. The crude product was purified by flash chromatography on silica gel to afford $230 \mathrm{mg}(56 \%)$ of the title compound as a white solid, m.p. $49-50{ }^{\circ} \mathrm{C},[\alpha]^{23}{ }_{\mathrm{D}}+6.1^{\circ}\left(c 1.0, \mathrm{CHCl}_{3}\right)$. Spectral data were identical to the racemic compound 9 described above. This material was judged to be of $97 \%$ ee using the method described below.

The enantiomeric purity of $\mathbf{9}$ was determined through HPLC analysis of the O-benzoyl derivative, which was prepared as follows: A flame-dried flask cooled under a stream of nitrogen was charged with +-9 (40 mg, $0.122 \mathrm{mmol})$, pyridine $(2 \mathrm{~mL})$ and cooled to $0{ }^{\circ} \mathrm{C}$. Neat benzoyl chloride $(90 \mu \mathrm{L}, 0.78$ mmol) was added dropwise. The resulting mixture was stirred at $0{ }^{\circ} \mathrm{C}$ until the starting material was consumed as judged by TLC analysis (ca. 1h). The reaction mixture was then diluted with water $(3 \mathrm{~mL})$ and ethyl acetate $(5 \mathrm{~mL})$. The layers were separated and the remaining aqueous phase was extracted with ethyl acetate $(3 \times 3 \mathrm{~mL})$. The combined organic extracts were dried over anhydrous $\mathrm{Na}_{2} \mathrm{SO}_{4}$, filtered and concentrated in vacuo before being purified using 10\% ethyl acetate/hexanes as the eluent to afford $47.5 \mathrm{mg}(90 \%)$ of a colorless oil. ${ }^{1} \mathrm{H} \mathrm{NMR}\left(500 \mathrm{MHz}, \mathrm{CDCl}_{3}\right) \delta 8.06(\mathrm{~d}, J=7.3 \mathrm{~Hz}, 2 \mathrm{H})$, $7.55(\mathrm{t}, J=7.3 \mathrm{~Hz}, 1 \mathrm{H}), 7.44(\mathrm{t}, J=7.8 \mathrm{~Hz}, 2 \mathrm{H}), 5.96-5.85(\mathrm{~m}, 1 \mathrm{H}), 5.63-5.55(\mathrm{~m}, 1 \mathrm{H}), 5.33(\mathrm{~d}, J=$ $17.1 \mathrm{~Hz}, 1 \mathrm{H}), 5.20(\mathrm{~d}, J=10.5 \mathrm{~Hz}, 1 \mathrm{H}), 4.45$ (s, br, $1 \mathrm{H}), 3.80-3.61$ (m, br, $1 \mathrm{H}), 2.04-1.91(\mathrm{~m}, 1 \mathrm{H})$, 1.85-1.75 (m, $1 \mathrm{H}), 1.57-1.15(\mathrm{~m}, 25 \mathrm{H}), 0.88(\mathrm{t}, J=6.8 \mathrm{~Hz}, 3 \mathrm{H}) ;{ }^{13} \mathrm{C} \mathrm{NMR}\left(100 \mathrm{MHz}, \mathrm{CDCl}_{3}\right) \delta$ 206.1, 165.6, 155.2, 136.3, 132.9, 130.4, 129.6, 128.3, 116.8, 78.9, 72.6, 48.5, 47.6, 40.8, 39.5, 36.5, $35.4,31.9,29.6,29.5,29.3,28.4,25.8,22.6,14.1$. 
Assay for determination of enantiomeric excess (ee): The O-benzoyl derivative of +-9 (10 mg) was dissolved in isopropanol $(50 \mu \mathrm{L})$ and hexanes $(1 \mathrm{~mL})$ and injected in an HPLC apparatus equipped with chiral column $(\mathrm{R}, \mathrm{R})$ WHELK-O 1 (Regis Tech.). The system permitting separation of enantiomers $(\mathrm{RT}=5.825 \mathrm{~min}$ and $6.733 \mathrm{~min})$ was found to be $5 \%$ isopropanol $/$ hexanes, flow rate $=1$ $\mathrm{mL} / \mathrm{min}$ at wavelength of $231 \mathrm{~nm}$. The HPLC analysis indicated the material was of $97 \%$ ee.

\section{(-)-(1R,3S)-3-(tert-Butyldimethylsilyloxy)-1-nonylpent-4-enylcarbamic acid tert-butyl ester (5).}

Treatment of $(+)-(1 R, 3 S)$-3-hydroxy-1-nonylpent-4-enylcarbamic acid tert-butyl ester (180 mg, 0.55 mmol) with TBS-Cl (133 mg, $0.88 \mathrm{mmol})$ and imidazole $(75 \mathrm{mg}, 1.1 \mathrm{mmol})$ using a procedure analogous to that described above for the synthesis of racemic compound $\mathbf{5}$ afforded the nonracemic title compound $(226 \mathrm{mg}, 93 \%)$ as a colorless oil, $[\alpha]_{\mathrm{D}}^{23}-1.3^{\circ}\left(c\right.$ 1.0, $\left.\mathrm{CHCl}_{3}\right)$. Spectral data were identical to the racemic compound $\mathbf{5}$ described above.

(-)-(2S,3S,5R)-2-Benzyl-3-(tert-butyldimethylsilyloxy)-5-nonylpyrrolidine-1-carboxylic acid tertbutyl ester (11). ${ }^{1}$ Treatment of (-)-(1R,3S)-3-(tert-butyldimethylsilyloxy)-1-nonylpent-4-enylcarbamic acid tert-butyl ester $(110 \mathrm{mg}, 0.25 \mathrm{mmol})$ with bromobenzene $(32 \mu \mathrm{L}, 0.3 \mathrm{mmol})$ using a procedure analogous to that described above for the synthesis of racemic compound $\mathbf{1 1}$ afforded the nonracemic title compound $(80.2 \mathrm{mg}, 62 \%)$ as a colorless oil, $[\alpha]_{\mathrm{D}}^{23}-51.8^{\circ}\left(c\right.$ 1.1, $\left.\mathrm{CHCl}_{3}\right)\left[\right.$ lit. $^{1}[\alpha]_{\mathrm{D}}^{20}-48.6^{\circ}(c$ 1.1, $\left.\mathrm{CHCl}_{3}\right)$ ]. Spectral data were identical to the racemic compound $\mathbf{1 1}$ described above. This material was judged to be of $96 \%$ ee using the method described below.

Assay for determination of enantiomeric excess (ee): Compound 11 (10 mg) was dissolved in isopropanol $(50 \mu \mathrm{L})$ and hexanes $(1 \mathrm{~mL})$ and injected in an HPLC apparatus equipped with chiral column (R,R) WHELK-O 1 (Regis Tech.). The system permitting separation of enantiomers $(\mathrm{RT}=$ $8.350 \mathrm{~min}$ and $9.433 \mathrm{~min}$ ) was found to be $2.5 \%$ isopropanol/hexanes, flow rate $=0.5 \mathrm{~mL} / \mathrm{min}$ at wavelength of $254 \mathrm{~nm}$. The HPLC analysis indicated the material was of $96 \%$ ee.

(+)-Preussin (1). ${ }^{2}$ Treatment of $\quad(-)-(2 S, 3 S, 5 R)-2$-benzyl-3-(tert-butyldimethylsilyloxy)-5nonylpyrrolidine-1-carboxylic acid tert-butyl ester $(27 \mathrm{mg}, 0.05 \mathrm{mmol})$ with $\mathrm{LiAlH}_{4}(313 \mu \mathrm{L}, 0.313$ 
mmol) using a procedure analogous to that described above for the synthesis of racemic compound 1 afforded the nonracemic title compound $(16 \mathrm{mg}, 95 \%)$ as a colorless oil, $[\alpha]^{23}{ }_{\mathrm{D}}+21.2^{\circ}\left(c 1.0, \mathrm{CHCl}_{3}\right)$ $\left[\right.$ lit. $\left.{ }^{5}[\alpha]^{25}+22.0^{\circ}\left(c 1.0, \mathrm{CHCl}_{3}\right)\right]$. Spectral data were identical to the racemic compound $\mathbf{1}$ described above.

\section{Synthesis of $\mathrm{N}$-boc-O-TBS Preussin and 3-epi-Preussin Analogs (Table 1).}

\section{(士)-(2S,3S,5R)-2-(4-Benzoylbenzyl)-3-(tert-butyldimethylsilyloxy)-5-nonylpyrrolidine-1-}

carboxylic acid tert-butyl ester (19). This compound was prepared on a $0.5 \mathrm{mmol}$ scale using a procedure analogous to that employed for the synthesis of $\mathbf{1 1}$ except 4-bromobenzophenone (157 $\mathrm{mg}$, $0.6 \mathrm{mmol}$ ) was used in place of bromobenzene. This procedure afforded $208 \mathrm{mg}(67 \%)$ of the title compound as a colorless oil. This compound was found to exist as a 1.5:1 mixture of rotamers as judged by ${ }^{1} \mathrm{H}$ NMR analysis; data are for the mixture. ${ }^{1} \mathrm{H}$ NMR $\left(400 \mathrm{MHz}, \mathrm{CDCl}_{3}\right) \delta$ 7.81-7.66 (m, 4 H), 7.59-7.52 (m, 1 H), 7.49-7.42 (m, 2 H), 7.40-7.29 (m, 2 H), 4.34-4.18 (m, 1.4 H), 4.15-4.00 (m, $0.6 \mathrm{H}), 3.74-3.50$ (m, $1 \mathrm{H}), 3.15-3.03$ (m, $1 \mathrm{H}), 2.89-2.75$ (m, $0.4 \mathrm{H}), 2.72-2.56$ (m, 0.6 H), 2.34-2.12 (m, 1.6 H), 2.08-1.93 (m, 0.4 H), 1.67-1.55 (m, $1 \mathrm{H}), 1.43-1.11(\mathrm{~m}, 24 \mathrm{H}), 0.95-0.82(\mathrm{~m}, 12 \mathrm{H})$, 0.13-0.07 (m, $6 \mathrm{H}) ;{ }^{13} \mathrm{C}$ NMR (100 MHz, $\left.\mathrm{CDCl}_{3}\right) \delta$ 196.3, 154.7, 145.6, 138.0, 135.0, 132.0, 130.0, 129.8, 129.7, 128.1, 79.1, 71.3, 62.0, 61.5, 55.6, 38.7, 38.0, 37.1, 36.2, 31.8, 29.6, 29.5, 29.2, 28.1, 26.5, 25.8, 22.6, 18.1, 14.1, -4.7, -5.0. IR (film) $1693,1661 \mathrm{~cm}^{-1}$. Anal calcd for $\mathrm{C}_{38} \mathrm{H}_{59} \mathrm{NO}_{4} \mathrm{Si}$ : C, 73.38; H, 9.56; N, 2.25. Found: C, 73.23; H, 9.67; N, 2.32.

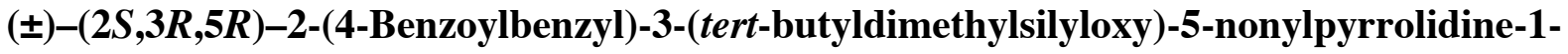

carboxylic acid tert-butyl ester (20). This compound was prepared on a $0.5 \mathrm{mmol}$ scale using a procedure analogous to that employed for the synthesis of 13 except 4-bromobenzophenone (157 $\mathrm{mg}$, $0.6 \mathrm{mmol}$ ) was used in place of bromobenzene. This procedure afforded $194.8 \mathrm{mg}(63 \%)$ of the title compound as a colorless oil. This compound was found to exist as a 1.5:1 mixture of rotamers as judged by ${ }^{1} \mathrm{H}$ NMR analysis and contained a small amount (ca 3-5\%) of an inseparable aromatic impurity; data are for the mixture. ${ }^{1} \mathrm{H}$ NMR $\left(400 \mathrm{MHz}, \mathrm{CDCl}_{3}\right) \delta 7.75-7.67(\mathrm{~m}, 4 \mathrm{H}), 7.56-7.48(\mathrm{~m}, 1$ H), 7.45-7.38 (m, 2 H), 7.34-7.21 (m, 2 H), 4.02-3.74 (m, 3 H), 3.13-3.00 (m, 0.4 H), 2.96-2.81 (m, $0.6 \mathrm{H}), 2.56-2.45$ (m, $1 \mathrm{H}), 2.18-2.03(\mathrm{~m}, 0.4 \mathrm{H}), 2.02-1.88$ (m, $1.6 \mathrm{H}), 1.85-1.66$ (m, $1 \mathrm{H}), 1.49-1.33$ $(\mathrm{m}, 10 \mathrm{H}), 1.31-1.10(\mathrm{~m}, 14 \mathrm{H}), 0.83(\mathrm{t}, J=6.6 \mathrm{~Hz}, 3 \mathrm{H}), 0.75-0.69(\mathrm{~m}, 9 \mathrm{H}),-0.17--0.27(\mathrm{~m}, 6 \mathrm{H}) ;{ }^{13} \mathrm{C}$ 
NMR (100 MHz, $\left.\mathrm{CDCl}_{3}\right) \delta 196.1,195.5,159.9,155.2,143.7,137.9,137.6,135.6,132.1,131.8,131.6$, 130.2, 129.8, 129.6, 129.2, 128.1, 128.0, 122.0, 79.4, 79.0, 73.3, 72.4, 69.3, 68.8, 57.2, 40.4, 39.6, 39.2, 38.8, 36.0, 38.0, 31.8, 29.6, 29.4, 29.2, 28.8, 28.3, 25.5, 22.5, 17.7, 14.0, -5.1, -5.2. IR (film) 1694, $1660 \mathrm{~cm}^{-1}$. Anal calcd for $\mathrm{C}_{38} \mathrm{H}_{59} \mathrm{NO}_{4} \mathrm{Si}: \mathrm{C}, 73.38 ; \mathrm{H}, 9.56 ; \mathrm{N}, 2.25$. Found: C, 73.68; H, 9.48; N, 2.16.

\section{(士)-(2S,3S,5R)-2-(4-Methoxybenzyl)-3-(tert-butyldimethylsilyloxy)-5-nonylpyrrolidine-1-}

carboxylic acid tert-butyl ester (21). This compound was prepared on a $0.5 \mathrm{mmol}$ scale using a procedure analogous to that employed for the synthesis of $\mathbf{1 1}$ except 4-bromoanisole (76 $\mu \mathrm{L}, 0.6 \mathrm{mmol}$ ) was used in place of bromobenzene. This procedure afforded $149.7 \mathrm{mg}$ (55\%) of the title compound as a colorless oil. This compound was found to exist as a 1.5:1 mixture of rotamers as judged by ${ }^{1} \mathrm{H}$ NMR analysis; data are for the mixture. ${ }^{1} \mathrm{H}$ NMR (400 MHz, $\left.\mathrm{CDCl}_{3}\right) \delta 7.20-7.04(\mathrm{~m}, 2 \mathrm{H}), 6.84-6.75$ (m, 2 H), 4.30-4.18 (m, 1 H), 4.17-4.08 (m, 0.4 H), 4.01-3.90 (m, 0.6 H), 3.77 (s, 3 H), 3.70-3.46 (m, $1 \mathrm{H})$, 2.99-2.89 (m, 1 H), 2.78-2.62 (m, 0.4 H), 2.56-2.41 (m, 0.6 H), 2.32-2.09 (m, 1.6 H), 2.01-1.86 (m, $0.4 \mathrm{H}), 1.63-1.50(\mathrm{~m}, 1 \mathrm{H}), 1.48-1.02$ (m, $24 \mathrm{H}), 0.97-0.79(\mathrm{~m}, 12 \mathrm{H}), 0.13--0.08(\mathrm{~m}, 6 \mathrm{H}) ;{ }^{13} \mathrm{C} \mathrm{NMR}$ $\left(100 \mathrm{MHz}, \mathrm{CDCl}_{3}\right) \delta 157.8,154.9,132.1,130.7,113.5,78.9,71.4,62.4,61.7,55.6,55.3,38.7,38.0$, 37.2, 34.9, 31.9, 29.7, 29.5, 29.3, 28.1, 26.5, 25.8, 22.7, 18.1, 14.1, -4.7, -5.0. IR (film) $1692 \mathrm{~cm}^{-1}$. Anal calcd for $\mathrm{C}_{32} \mathrm{H}_{57} \mathrm{NO}_{4} \mathrm{Si}:$ C, 70.15; H, 10.49; N, 2.56. Found: C, 70.08; H, 10.30; N, 2.52.

\section{(士)-(2S,3S,5R)-2-(4-Methoxybenzyl)-3-(tert-butyldimethylsilyloxy)-5-nonylpyrrolidine-1-}

carboxylic acid tert-butyl ester (22). This compound was prepared on a 0.5 mmol scale using a procedure analogous to that employed for the synthesis of 13 except 4-bromoanisole ( $76 \mu \mathrm{L}, 0.6 \mathrm{mmol}$ ) was used in place of bromobenzene. This procedure afforded $131.2 \mathrm{mg}(48 \%)$ of the title compound as a colorless oil. This compound was found to exist as a $\sim 1.5: 1$ mixture of rotamers as judged by ${ }^{1} \mathrm{H}$ NMR analysis; data are for the mixture. ${ }^{1} \mathrm{H}$ NMR $\left(500 \mathrm{MHz}, \mathrm{CDCl}_{3}\right) \delta 7.19-7.03$ (m, $\left.2 \mathrm{H}\right), 6.86-6.78$ $(\mathrm{m}, 2 \mathrm{H}), 4.00-3.96(\mathrm{~m}, 1 \mathrm{H}), 3.95-3.85(\mathrm{~m}, 1 \mathrm{H}), 3.84-3.73(\mathrm{~m}, 4 \mathrm{H}), 3.04-2.93(\mathrm{~m}, 0.35 \mathrm{H})$, 2.86-2.76 (m, 0.65 H), 2.40-2.31 (m, 1 H), 2.17-2.05 (m, 0.65 H), 2.00-1.86 (m, 1 H), 1.85-1.77 (m, $0.35 \mathrm{H}), 1.76-1.67(\mathrm{~m}, 1 \mathrm{H}), 1.53-1.37(\mathrm{~m}, 10 \mathrm{H}), 1.35-1.12(\mathrm{~m}, 14 \mathrm{H}), 0.88(\mathrm{t}, J=6.3 \mathrm{~Hz}, 3 \mathrm{H}), 0.75$ (s, $9 \mathrm{H}),-0.17--0.26(\mathrm{~m}, 6 \mathrm{H}) ;{ }^{13} \mathrm{C} \mathrm{NMR}\left(125 \mathrm{MHz}, \mathrm{CDCl}_{3}\right) \delta 158.1,155.4,130.9,130.2,113.8,78.8$, 73.2, 72.3, 69.8, 69.2, 57.2, 55.3, 39.5, 38.9, 38.7, 36.0, 31.9, 29.7, 29.5, 29.3, 28.5, 26.1, 25.9, 25.6, 22.7, 17.8, 14.1, -5.08, -5.13. IR (film) $1694 \mathrm{~cm}^{-1}$. Anal calcd for $\mathrm{C}_{32} \mathrm{H}_{57} \mathrm{NO}_{4} \mathrm{Si}: \mathrm{C}, 70.15 ; \mathrm{H}, 10.49 ; \mathrm{N}$, 2.56. Found: C, 70.01; H, 10.64; N, 2.53. 
(士)-(2S,3S,5R)-2-(4-Trifluoromethylbenzyl)-3-(tert-butyldimethylsilyloxy)-5-nonylpyrrolidine-1carboxylic acid tert-butyl ester (23). This compound was prepared on a $0.5 \mathrm{mmol}$ scale using a procedure analogous to that employed for the synthesis of $\mathbf{1 1}$ except 4-bromobenzotrifluoride $(85 \mu \mathrm{L}$, $0.6 \mathrm{mmol})$ was used in place of bromobenzene. This procedure afforded $201.3 \mathrm{mg}(69 \%)$ of the title compound as a colorless oil. This compound was found to exist as a 1.5:1 mixture of rotamers as judged by ${ }^{1} \mathrm{H}$ NMR analysis; data are for the mixture. ${ }^{1} \mathrm{H}$ NMR $\left(400 \mathrm{MHz}, \mathrm{CDCl}_{3}\right) \delta 7.56-7.43(\mathrm{~m}, 2$ H), 7.41-7.25 (m, $2 \mathrm{H}), 4.32-4.15(\mathrm{~m}, 1.4 \mathrm{H}), 4.06-3.93(\mathrm{~m}, 0.6 \mathrm{H}), 3.72-3.45(\mathrm{~m}, 1 \mathrm{H}), 3.10-3.00$ (m, $1 \mathrm{H}), 2.86-2.72(\mathrm{~m}, 0.4 \mathrm{H}), 2.65-2.51(\mathrm{~m}, 0.6 \mathrm{H}), 2.36-2.11(\mathrm{~m}, 1.6 \mathrm{H}), 2.05-1.90(\mathrm{~m}, 0.4 \mathrm{H})$, 1.65-1.54 (m, $1 \mathrm{H}), 1.45-1.00(\mathrm{~m}, 24 \mathrm{H}), 0.99-0.78(\mathrm{~m}, 12 \mathrm{H}), 0.14--0.11(\mathrm{~m}, 6 \mathrm{H}) ;{ }^{13} \mathrm{C}$ NMR $(100$ $\left.\mathrm{MHz}, \mathrm{CDCl}_{3}\right) \delta 154.8,144.4,130.1,128.1$ (q, $\left.J=25.0 \mathrm{~Hz}\right), 124.9,124.4(\mathrm{q}, J=271.8 \mathrm{~Hz}), 79.2,71.3$, 62.2, 61.3, 56.5, 55.7, 38.8, 38.0, 37.3, 36.0, 31.9, 29.6, 29.5, 29.3, 28.3, 28.0, 26.5, 25.8, 22.7, 18.1, 14.1, -4.7, -5.0; IR (film) $1695 \mathrm{~cm}^{-1}$. Anal calcd for $\mathrm{C}_{32} \mathrm{H}_{54} \mathrm{~F}_{3} \mathrm{NO}_{3} \mathrm{Si}$ : C, 65.60; H, 9.29; N, 2.39. Found: C, 65.57; H, 9.40; N, 2.37.

\section{(士)-(2S,3R,5R)-2-(4-Trifluoromethylbenzyl)-3-(tert-butyldimethylsilyloxy)-5-nonylpyrrolidine-1-} carboxylic acid tert-butyl ester (24). This compound was prepared on a 0.5 mmol scale using a procedure analogous to that employed for the synthesis of 13 except 4-bromobenzotrifluoride $(85 \mu \mathrm{L}$, $0.6 \mathrm{mmol})$ was used in place of bromobenzene. This procedure afforded $152 \mathrm{mg}(52 \%)$ of the title compound as a colorless oil. This compound was found to exist as a 1.5:1 mixture of rotamers as judged by ${ }^{1} \mathrm{H}$ NMR analysis; data are for the mixture. ${ }^{1} \mathrm{H}$ NMR $\left(500 \mathrm{MHz}, \mathrm{CDCl}_{3}\right) \delta 7.58-7.50(\mathrm{~m}, 2$ H), 7.38-7.24 (m, 2 H), 4.03-3.77 (m, 3 H), 3.13-3.04 (m, 0.4 H), 2.89-2.79 (m, 0.6 H), 2.58-2.51 (m, $1 \mathrm{H}), 2.17-2.07(\mathrm{~m}, 0.6 \mathrm{H}), 2.09-1.90(\mathrm{~m}, 1.4 \mathrm{H}), 1.80-1.70(\mathrm{~m}, 1 \mathrm{H}), 1.55-1.11(\mathrm{~m}, 24 \mathrm{H}), 0.88(\mathrm{t}, J=$ $6.6 \mathrm{~Hz}, 3 \mathrm{H}), 0.75(\mathrm{~s}, 9 \mathrm{H}),-0.13--0.27(\mathrm{~m}, 6 \mathrm{H}) ;{ }^{13} \mathrm{C} \mathrm{NMR}\left(125 \mathrm{MHz}, \mathrm{CDCl}_{3}\right) \delta$ 155.3, 142.9, 129.7, $128.7(\mathrm{q}, J=32.2 \mathrm{~Hz}), 125.2,124.3(\mathrm{q}, J=272.0 \mathrm{~Hz}), 79.1,73.6,72.4,69.3,68.7,57.4,57.1,40.3$, $39.3,39.0,36.3,31.9,29.7,29.5,29.3,28.4,26.2,25.9,25.5,22.7,17.8,14.1$, -5.0, -5.2; IR (film) $1694 \mathrm{~cm}^{-1}$. Anal calcd for $\mathrm{C}_{32} \mathrm{H}_{54} \mathrm{~F}_{3} \mathrm{NO}_{3} \mathrm{Si}: \mathrm{C}, 65.60 ; \mathrm{H}, 9.29 ; \mathrm{N}, 2.39$. Found: C, 65.78; H, 9.48; N, 2.48 .

(士)-(2S,3S,5R)-2-(Naphthalen-2-ylmethyl)-3-(tert-butyldimethylsilyloxy)-5-nonylpyrrolidine-1carboxylic acid tert-butyl ester (25). This compound was prepared on a $0.5 \mathrm{mmol}$ scale using a procedure analogous to that employed for the synthesis of 11 except 2-bromonaphthalene (125 $\mathrm{mg}, 0.6$ $\mathrm{mmol})$ was used in place of bromobenzene. This procedure afforded $187.9 \mathrm{mg}(66 \%)$ of the title 
compound as a pale orange oil. This compound was found to exist as a 3:1 mixture of rotamers as judged by ${ }^{1} \mathrm{H}$ NMR analysis; data are for the mixture. ${ }^{1} \mathrm{H}$ NMR $\left(400 \mathrm{MHz}, \mathrm{CDCl}_{3}\right) \delta 7.82-7.71$ (m, 3 H), 7.69-7.59 (m, 1 H), 7.51-7.31 (m, 3 H), 4.36-4.23 (m, 1.25 H), 4.18-4.02 (m, 0.75 H), 3.76-3.50 (m, 1 H), 3.24-3.14 (m, 1 H), 3.06-2.88 (m, 0.25 H), 2.81-2.64 (m, 0.75 H), 2.38-2.11 (m, 1.75 H), 2.03-1.90 (m, 0.25 H), 1.71-1.58 (m, 1 H), 1.47-1.12 (m, $20 \mathrm{H}), 1.05-0.79(\mathrm{~m}, 16 \mathrm{H}), 0.16--0.14(\mathrm{~m}$, $6 \mathrm{H}) ;{ }^{13} \mathrm{C} \mathrm{NMR}\left(100 \mathrm{MHz}, \mathrm{CDCl}_{3}\right) \delta 154.9,137.6,133.5,132.0,128.6,128.0,127.4,127.3,125.6$, 124.9, 78.8, 71.4, 62.4, 61.6, 55.7, 38.7, 38.0, 37.2, 36.2, 31.9, 29.6, 29.5, 29.3, 28.3, 27.8, 26.5, 25.8, 22.7, 18.1, 14.1, -4.7, -5.0 (two aromatic carbons are incidentally equivalent); IR (film) $1693 \mathrm{~cm}^{-1}$. Anal calcd for $\mathrm{C}_{35} \mathrm{H}_{57} \mathrm{NO}_{3} \mathrm{Si}: \mathrm{C}, 74.02 ; \mathrm{H}, 10.12 ; \mathrm{N}, 2.47$. Found: C, 73.89; H, 10.28; N, 2.55.

\section{(士)-(2S,3S,5R)-2-(2-Methylbenzyl)-3-(tert-butyldimethylsilyloxy)-5-nonylpyrrolidine-1-}

carboxylic acid tert-butyl ester (26). This compound was prepared on a $0.5 \mathrm{mmol}$ scale using a procedure analogous to that employed for the synthesis of $\mathbf{1 1}$ except 2-bromotoluene $(66 \mu \mathrm{L}, 0.6$ $\mathrm{mmol})$ was used in place of bromobenzene. This procedure afforded $148.3 \mathrm{mg}(56 \%)$ of the title compound as a pale yellow oil. This compound was found to exist as a 9:1 mixture of rotamers as judged by ${ }^{1} \mathrm{H}$ NMR analysis; data are for the mixture. ${ }^{1} \mathrm{H}$ NMR (400 $\left.\mathrm{MHz}, \mathrm{CDCl}_{3}\right) \delta 7.15-7.03$ (m, 4 H), 4.31-4.20 (m, 1 H), 4.10-3.99 (m, 0.9 H), 3.88-3.78 (m, 0.1 H), 3.71-3.57 (m, 1 H), 3.29-3.12 (m, $1 \mathrm{H}), 2.56-2.46$ (m, 0.1 H), 2.40-2.19 (m, 5.8 H), 2.10-2.00 (m, 0.1 H), 1.72-1.61 (m, $1 \mathrm{H}), 1.46-1.19$ $(\mathrm{m}, 20 \mathrm{H}), 1.09-0.82(\mathrm{~m}, 16 \mathrm{H}), 0.16--0.04(\mathrm{~m}, 6 \mathrm{H}) ;{ }^{13} \mathrm{C} \mathrm{NMR}\left(100 \mathrm{MHz}, \mathrm{CDCl}_{3}\right) \delta 154.9,138.1$, $136.4,130.7,129.9,125.8,125.7,78.7,71.2$, 60.0, 55.7, 38.0, 37.7, 33.3, 31.9, 29.8, 29.7, 29.5, 29.3, 27.7, 26.7, 25.8, 25.7, 22.7, 19.6, 18.0, 14.1, -4.8, -5.1; IR (film) $1693 \mathrm{~cm}^{-1}$. Anal calcd for $\mathrm{C}_{32} \mathrm{H}_{57} \mathrm{NO}_{3} \mathrm{Si}: \mathrm{C}, 72.26 ; \mathrm{H}, 10.80 ; \mathrm{N}, 2.63$. Found: C, 72.07; H, 10.65; N, 2.62.

\section{(士)-(2S,3S,5R)-2-(4-Cyanobenzyl)-3-(tert-butyldimethylsilyloxy)-5-nonylpyrrolidine-1-carboxylic}

acid tert-butyl ester (27). This compound was prepared on a $0.5 \mathrm{mmol}$ scale using a procedure analogous to that employed for the synthesis of 11 except 4-bromobenzonitrile (110 $\mathrm{mg}, 0.6 \mathrm{mmol}$ ) was used in place of bromobenzene. This procedure afforded $175 \mathrm{mg}(65 \%)$ of the title compound as a colorless oil. This compound was found to exist as a 1.5:1 mixture of rotamers as judged by ${ }^{1} \mathrm{H}$ NMR analysis; data are for the mixture. ${ }^{1} \mathrm{H}$ NMR $\left(500 \mathrm{MHz}, \mathrm{CDCl}_{3}\right) \delta 7.63-7.48(\mathrm{~m}, 2 \mathrm{H}), 7.43-7.23(\mathrm{~m}, 2$ H), 4.34-4.21 (m, $1 \mathrm{H}), 4.20-4.11(\mathrm{~m}, 0.4 \mathrm{H}), 4.05-3.92(\mathrm{~m}, 0.6 \mathrm{H}), 3.74-3.45(\mathrm{~m}, 1 \mathrm{H}), 3.05(\mathrm{dd}, J=$ 5.1, 13.7, 1 H), 2.81-2.67 (m, 0.4 H), 2.66-2.51 (m, 0.6 H), 2.36-2.10 (m, 1.6 H), 2.06-1.86 (m, 0.4 $\mathrm{H}), 1.75-1.50(\mathrm{~m}, 1 \mathrm{H}), 1.49-1.04(\mathrm{~m}, 24 \mathrm{H}), 0.96-0.76(\mathrm{~m}, 12 \mathrm{H}), 0.14-0.11(\mathrm{~m}, 6 \mathrm{H}) ;{ }^{13} \mathrm{C}$ NMR 
$\left(125 \mathrm{MHz} \mathrm{CDCl}_{3}\right) \delta 154.7,146.1,131.8,130.6,119.2,109.4,79.3,71.3,70.9,62.0,61.3,55.6,38.7$, 37.9, 37.2, 36.5, 31.9, 29.7, 29.5, 29.3, 28.1, 26.5, 25.8, 22.6, 18.0, 14.1, -4.7, -5.0; IR (film) $1694 \mathrm{~cm}^{-1}$. Anal calcd for $\mathrm{C}_{32} \mathrm{H}_{54} \mathrm{~N}_{2} \mathrm{O}_{3} \mathrm{Si}: \mathrm{C}, 70.80 ; \mathrm{H}, 10.03 ; \mathrm{N}, 5.16$. Found: C, 70.99; H, 9.90; N, 5.34.

\section{(士)-(2S,3S,5R)-2-(3-pyridyl-2-ylmethyl)-3-(tert-butyldimethylsilyloxy)-5-nonylpyrrolidine-1-}

carboxylic acid tert-butyl ester (28). This compound was prepared on a 0.5 mmol scale using a procedure analogous to that employed for the synthesis of 11 except 3-bromopyridine (60_L, 0.6 mmol) was used in place of bromobenzene. This procedure afforded $150.8 \mathrm{mg}(58 \%)$ of the title compound as a colorless oil. This compound was found to exist as a 1.5:1 mixture of rotamers as judged by ${ }^{1} \mathrm{H}$ NMR analysis; data are for the mixture. ${ }^{1} \mathrm{H}$ NMR (400 $\left.\mathrm{MHz}, \mathrm{CDCl}_{3}\right) \delta 8.47-8.34$ (m, 2 H), 7.64-7.41 (m, 1 H), 7.20-7.10 (m, 1 H), 4.30-4.20 (m, 1 H), 4.19-4.11 (m, 0.35 H), 4.02-3.90 (m, 0.65 H), 3.69-3.44 (m, 1 H), 3.02-2.92 (m, 1 H), 2.77-2.64 (m, 0.35 H), 2.57-2.44 (m, 0.65 H), 2.34-2.08 (m, 1.65 H), 2.02-1.90 (m, 0.35 H), 1.60-1.47 (m, 1 H), 1.44-1.04 (m, 24 H), 0.94-0.77 (m, $12 \mathrm{H}), 0.13--0.13(\mathrm{~m}, 6 \mathrm{H}) ;{ }^{13} \mathrm{C} \mathrm{NMR}\left(100 \mathrm{MHz}, \mathrm{CDCl}_{3}\right) \delta 154.7,151.1,147.0,137.1,135.4,122.9$, 79.2, 71.2, 62.0, 61.1, 55.6, 38.8, 37.9, 37.2, 33.3, 31.8, 29.6, 29.5, 29.2, 28.0, 26.4, 25.8, 22.6, 18.0, 14.0, -4.8, -5.1; IR (film) $1694 \mathrm{~cm}^{-1}$. Anal calcd for $\mathrm{C}_{30} \mathrm{H}_{54} \mathrm{~N}_{2} \mathrm{O}_{3} \mathrm{Si}$ : C, 69.45; H, 10.49; N, 5.40. Found: C, 69.50; H, 10.45; N, 5.34.

\section{(士)-(2S,3S,5R)-2-(N-benzyl-5-indolyl-2-ylmethyl)-3-(tert-butyldimethylsilyloxy)-5-}

nonylpyrrolidine-1-carboxylic acid tert-butyl ester (29). This compound was prepared on a 0.5 mmol scale using a procedure analogous to that employed for the synthesis of 11 except $N$-benzyl-5bromoindole $(172 \mathrm{mg}, 0.6 \mathrm{mmol})$ was used in place of bromobenzene. This procedure afforded 135.9 mg $(42 \%)$ of the title compound as a colorless oil. This compound was found to exist as a 1.5:1 mixture of rotamers as judged by ${ }^{1} \mathrm{H}$ NMR analysis; data are for the mixture. ${ }^{1} \mathrm{H}$ NMR $(400 \mathrm{MHz}$, $\left.\mathrm{CDCl}_{3}\right) \delta 7.53-7.40(\mathrm{~m}, 1 \mathrm{H}), 7.30-7.20(\mathrm{~m}, 3 \mathrm{H}), 7.18-6.96(\mathrm{~m}, 5 \mathrm{H}), 6.48-6.43$ (m, $\left.1 \mathrm{H}\right), 5.30(\mathrm{~s}, 2$ H), 4.31-4.21 (m, 1 H), 4.10-3.99 (m, 1 H), 3.79-3.50 (m, 1 H), 3.16-3.06 (m, 1 H), 2.95-2.77 (m, 0.4 H), 2.69-2.53 (m, 0.6 H), 2.34-2.12 (m, 1.6 H), 2.08-1.86 (m, 0.4 H), 1.70-1.58 (m, $1 \mathrm{H}), 1.46-1.13$ $(\mathrm{m}, 18 \mathrm{H}), 1.03-0.81(\mathrm{~m}, 18 \mathrm{H}), 0.13--0.14(\mathrm{~m}, 6 \mathrm{H}) ;{ }^{13} \mathrm{C} \mathrm{NMR}\left(100 \mathrm{MHz}, \mathrm{CDCl}_{3}\right) \delta 155.0,137.9$, 135.0, 130.8, 128.9, 128.6, 128.1, 127.4, 126.6, 124.0, 121.7, 109.1, 101.2, 78.6, 71.4, 62.8, 55.6, 50.0, 38.0, 37.3, 35.8, 35.2, 31.9, 29.73, 29.67, 29.5, 29.3, 28.5, 27.9, 26.6, 25.9, 25.7, 22.7, 18.1, 14.1, -4.7, -5.0; IR (film) $1689 \mathrm{~cm}^{-1}$. Anal calcd for $\mathrm{C}_{40} \mathrm{H}_{62} \mathrm{~N}_{2} \mathrm{O}_{3}$ Si: C, 74.25; H, 9.66; N, 4.33. Found: C, 73.87; H, $9.90 ; \mathrm{N}, 4.31$. 


\section{( \pm -(2S,3S,5R)-2-(4-Chlorobenzyl)-3-(tert-butyldimethylsilyloxy)-5-nonylpyrrolidine-1-}

carboxylic acid tert-butyl ester (30). This compound was prepared on a $0.5 \mathrm{mmol}$ scale using a procedure analogous to that employed for the synthesis of 11 except 4-bromochlorobenzene (115 mg, $0.6 \mathrm{mmol})$ was used in place of bromobenzene. This procedure afforded $195.4 \mathrm{mg}(71 \%)$ of the title compound as a pale orange oil. This compound was found to exist as a 1.5:1 mixture of rotamers as judged by ${ }^{1} \mathrm{H}$ NMR analysis; data are for the mixture. ${ }^{1} \mathrm{H}$ NMR $\left(400 \mathrm{MHz}, \mathrm{CDCl}_{3}\right) \delta 7.32-7.09$ (m, 4 $\mathrm{H}), 4.33-4.22(\mathrm{~m}, 1 \mathrm{H}), 4.21-4.11(\mathrm{~m}, 0.35 \mathrm{H}), 4.05-3.93(\mathrm{~m}, 0.65 \mathrm{H}), 3.73-3.51$ (m, $1 \mathrm{H}), 3.04-2.94$ (m, $1 \mathrm{H}), 2.79-2.65(\mathrm{~m}, 0.35 \mathrm{H}), 2.60-2.46(\mathrm{~m}, 0.65 \mathrm{H}), 2.36-2.13(\mathrm{~m}, 1.65 \mathrm{H}), 2.04-1.94(\mathrm{~m}, 0.35 \mathrm{H})$, 1.66-1.49 (m, 1 H), 1.48-1.08 (m, $24 \mathrm{H}), 0.99-0.81(\mathrm{~m}, 12 \mathrm{H}), 0.17--0.08(\mathrm{~m}, 6 \mathrm{H}) ;{ }^{13} \mathrm{C}$ NMR (100 $\left.\mathrm{MHz}, \mathrm{CDCl}_{3}\right) \delta 154.8,138.5,131.4,131.2,128.0,79.1,71.3,62.2,61.5,55.6,38.7,38.0,37.2,35.4$, $31.9,29.6,29.5,29.3,28.0,26.5,25.8,25.7,25.5,22.6,18.0,14.1,-4.7,-5.0$; IR (film) $1694 \mathrm{~cm}^{-1}$. Anal calcd for $\mathrm{C}_{31} \mathrm{H}_{54} \mathrm{ClNO}_{3} \mathrm{Si}$ : C, 67.41; H, 9.85; N, 6.42. Found: C, 67.25; H, 9.82; N, 2.54 .

\section{Synthesis of Deprotected Preussin and 3-epi-Preussin Analogs (Table 2)}

(士)-(2S,3S,5R)-2-(4-Benzoylbenzyl)-3-hydroxy-5-nonylpyrrolidine (31). A flame-dried flask cooled under a steam of nitrogen was charged with $19(62.2 \mathrm{mg}, 0.1 \mathrm{mmol})$ and tetrahydrofuran $(1 \mathrm{~mL})$. Formic acid ( $1 \mathrm{~mL}, 26.5 \mathrm{mmol})$ was added dropwise and the resulting mixture was stirred at $60{ }^{\circ} \mathrm{C}$ until the starting material was consumed as judged by TLC analysis (ca. 5h). The reaction mixture was then cooled to $0{ }^{\circ} \mathrm{C}$, an aqueous solution of formaldehyde (100 $\mu \mathrm{L}, 1.2 \mathrm{mmol}, 37 \mathrm{wt} \%$ ) was added dropwise, and the mixture was stirred at $0{ }^{\circ} \mathrm{C}$ for $1 \mathrm{~h}$. The reaction mixture was then heated to $60{ }^{\circ} \mathrm{C}$ with stirring for $12 \mathrm{~h}$. The crude mixture was cooled to $\mathrm{rt}$ and was concentrated in vacuo using a rotary evaporator, with trace residual solvent removed under high vacuum for $30 \mathrm{~min}$. The resulting residue was then dissolved in tetrahydrofuran $(1 \mathrm{~mL})$. Solid $\mathrm{K}_{2} \mathrm{CO}_{3}(150 \mathrm{mg}, 1.1 \mathrm{mmol})$ was added and the resulting suspension was cooled to $0^{\circ} \mathrm{C}$. A solution of TBAF ( $1 \mathrm{~mL}, 1 \mathrm{mmol}, 1 \mathrm{M}$ in tetrahydrofuran) was then added dropwise and the reaction was stirred at $\mathrm{rt}$ until the silyl protecting group was completely removed as judged by crude ${ }^{1} \mathrm{H}$ NMR analysis of an aliquot from the reaction mixture (ca. 5h). The crude mixture was concentrated in vacuo using a rotary evaporator, with trace residual solvent removed under high vacuum for $30 \mathrm{~min}$. The crude material was purified by flash chromatography using $5 \% \mathrm{MeOH} / \mathrm{CH}_{2} \mathrm{Cl}_{2}$ as the eluent to afford $36 \mathrm{mg}(85 \%)$ of the title compound as a light brown solid, m.p. 50-52 ${ }^{\circ} \mathrm{C} .{ }^{1} \mathrm{H}$ NMR $\left(500 \mathrm{MHz}, \mathrm{CDCl}_{3}\right) \delta 7.79(\mathrm{~d}, J=8.1 \mathrm{~Hz}, 2 \mathrm{H}), 7.74(\mathrm{t}, J=8.1 \mathrm{~Hz}, 2 \mathrm{H})$, 
7.60-7.56 (m, $1 \mathrm{H}), 7.48$ (t, $J=7.6 \mathrm{~Hz}, 2 \mathrm{H}), 7.42$ (d, $J=8.1 \mathrm{~Hz}, 2 \mathrm{H}), 3.84-3.78$ (m, $1 \mathrm{H}), 3.02-2.95$ (m, 1 H), 2.94-2.89 (m, $1 \mathrm{H}), 2.39-2.30$ (m, $4 \mathrm{H}), 2.29-2.20$ (m, 1 H), 2.19-2.13 (m, $1 \mathrm{H}), 2.08-1.95$ (s, br, $1 \mathrm{H}), 1.77-1.68(\mathrm{~m}, 1 \mathrm{H}), 1.48-1.42(\mathrm{~m}, 1 \mathrm{H}), 1.38-1.17(\mathrm{~m}, 15 \mathrm{H}), 0.88(\mathrm{t}, \mathrm{J}=6.8 \mathrm{~Hz}, 3 \mathrm{H})$; ${ }^{13} \mathrm{C}$ NMR $\left(125 \mathrm{MHz} \mathrm{CDCl}_{3}\right) \delta 196.5,144.6,137.8,135.5,132.2,130.3,130.0,129.3,128.2,73.2,70.4$, 65.7, 39.4, 38.6, 34.9, 33.8, 31.9, 29.9, 29.6, 29.5, 29.3, 26.2, 22.7, 14.1; IR (film) 3411, $1656 \mathrm{~cm}^{-1}$; MS (ESI): 422.3058 (422.3059 calculated for $\mathrm{C}_{28} \mathrm{H}_{39} \mathrm{NO}_{2}, \mathrm{M}+\mathrm{H}^{+}$).

( \pm )-(2S,3R,5R)-2-(4-Benzoylbenzyl)-3-hydroxy-5-nonylpyrrolidine (32). This compound was prepared on a $0.1 \mathrm{mmol}$ scale using a procedure analogous to that employed for the synthesis of $\mathbf{3 1}$. Substrate $20(62.2 \mathrm{mg}, 0.1 \mathrm{mmol})$ was transformed to the title compound to afford $36.2 \mathrm{mg}(86 \%)$ of a light brown solid, m.p. 62-64 ${ }^{\circ} \mathrm{C} .{ }^{1} \mathrm{H}$ NMR (500 MHz, $\left.\mathrm{CDCl}_{3}\right) \delta 7.79-7.72(\mathrm{~m}, 4 \mathrm{H}), 7.57$ (t, J= 7.6 $\mathrm{Hz}, 1 \mathrm{H}), 7.47$ (t, $J=7.8 \mathrm{~Hz}, 2 \mathrm{H}), 7.37$ (d, $J=8.1 \mathrm{~Hz}, 2 \mathrm{H}), 4.02-3.97$ (m, $1 \mathrm{H}), 3.05$ (dd, $J=4.9,13.7$ Hz, $1 \mathrm{H}), 2.74-2.67$ (m, 1 H), 2.57-2.46 (m, $2 \mathrm{H}), 2.34$ (s, $3 \mathrm{H}), 1.81-1.75$ (m, 1 H), 1.72-1.57 (m, 2 $\mathrm{H}), 1.35-1.11(\mathrm{~m}, 16 \mathrm{H}), 0.87(\mathrm{t}, J=6.8 \mathrm{~Hz}, 3 \mathrm{H}) ;{ }^{13} \mathrm{C} \mathrm{NMR}\left(125 \mathrm{MHz}, \mathrm{CDCl}_{3}\right) \delta$ 196.4, 144.3, 137.7, $135.5,132.3,130.3,129.9,129.3,128.2,76.8,74.5,64.8,39.5,39.4,39.3,33.8,31.8,29.9,29.58$, 29.53, 29.3, 26.3, 22.6, 14.1; IR (film) 3422, $1658 \mathrm{~cm}^{-1}$; MS (ESI): 422.3057 (422.3059 calculated for $\left.\mathrm{C}_{28} \mathrm{H}_{39} \mathrm{NO}_{2}, \mathrm{M}+\mathrm{H}^{+}\right)$.

(士)-(2S,3S,5R)-2-(4-Methoxybenzyl)-3-hydroxy-5-nonylpyrrolidine (33). A flame-dried flask was cooled under a stream of nitrogen and charged with 21 (100 mg, $0.2 \mathrm{mmol})$ and tetrahydrofuran (1 $\mathrm{mL})$. The resulting solution was cooled to $0{ }^{\circ} \mathrm{C}$ and $\mathrm{LiAlH}_{4}(2 \mathrm{~mL}, 2 \mathrm{mmol}, 1 \mathrm{M}$ in tetrahydrofuran $)$ was added dropwise via syringe. The resulting mixture was stirred at $60{ }^{\circ} \mathrm{C}$ until the starting material was consumed as judged by TLC analysis (ca. 16h). The reaction mixture was diluted with dry ether (2 $\mathrm{mL})$, cooled to $0{ }^{\circ} \mathrm{C}$ and slowly quenched with an aqueous saturated solution of $\mathrm{Na}_{2} \mathrm{SO}_{4}(0.3 \mathrm{~mL})$. The heterogeneous mixture was diluted with additional ether $(2 \mathrm{~mL})$ and was filtered through a small pad of celite. The filter was washed with additional ether and the combined organic filtrates were dried over $\mathrm{Na}_{2} \mathrm{SO}_{4}$, filtered and concentrated in vacuo. The crude oil obtained was purified by flash chromatography using $5 \% \mathrm{MeOH} / \mathrm{CH}_{2} \mathrm{Cl}_{2}$ as the eluent to afford $62.8 \mathrm{mg}(87 \%)$ of the title compound as a white solid, m.p. $47-49^{\circ} \mathrm{C} .{ }^{1} \mathrm{H}$ NMR $\left(400 \mathrm{MHz}, \mathrm{CDCl}_{3}\right) \delta 7.21(\mathrm{~d}, J=8.6 \mathrm{~Hz}, 2 \mathrm{H}), 6.83(\mathrm{~d}, J=$ 8.6 Hz, 2H), 3.83-3.76 (m, 4 H), 2.83-2.76 (m, 2 H), 2.33 (s, $3 \mathrm{H}), 2.26-2.06$ (m, 3 H), 1.94-1.74 (m, $1 \mathrm{H}), 1.76-1.55(\mathrm{~m}, 2 \mathrm{H}), 1.45-1.38(\mathrm{~m}, 1 \mathrm{H}), 1.37-1.16(\mathrm{~m}, 14 \mathrm{H}), 0.88(\mathrm{t}, J=6.6 \mathrm{~Hz}, 3 \mathrm{H}) ;{ }^{13} \mathrm{C} \mathrm{NMR}$ $\left(100 \mathrm{MHz}, \mathrm{CDCl}_{3}\right) \delta 158.0,131.1,130.2,113.8,73.9,70.3,66.0,55.2,39.2,38.5,34.6,32.5,31.9$, 
29.8, 29.6, 29.5, 29.3, 26.3, 22.7, 14.1; IR (film) $3412 \mathrm{~cm}^{-1}$; MS (ESI): 348.2902 (348.2903 calculated for $\mathrm{C}_{22} \mathrm{H}_{37} \mathrm{NO}_{2}, \mathrm{M}+\mathrm{H}^{+}$).

( \pm -(2S,3R,5R)-2-(4-Methoxybenzyl)-3-hydroxy-5-nonylpyrrolidine (34). This compound was prepared on a $0.2 \mathrm{mmol}$ scale using a procedure analogous to that employed for the synthesis of $\mathbf{3 3}$ except that removal of the silyl group required the use of TBAF after LAH reduction (see 31 for protocol, $\mathrm{K}_{2} \mathrm{CO}_{3}$ was not used). Substrate $22(110 \mathrm{mg}, 0.2 \mathrm{mmol})$ was transformed to the title compound to afford $63.2 \mathrm{mg}(88 \%)$ of a white solid, m.p. $49-50{ }^{\circ} \mathrm{C}$. ${ }^{1} \mathrm{H}$ NMR $\left(400 \mathrm{MHz}, \mathrm{CDCl}_{3}\right)$ $\delta 7.18(\mathrm{~d}, J=8.5 \mathrm{~Hz}, 2 \mathrm{H}), 6.85(\mathrm{~d}, J=8.5 \mathrm{~Hz}, 2 \mathrm{H}), 4.03-3.96(\mathrm{~m}, 1 \mathrm{H}), 3.79(\mathrm{~s}, 3 \mathrm{H}), 3.05-2.97$ (m, 1 H), 2.55-2.41 (m, 2 H), 2.40-2.32 (m, 4 H), 1.80-1.73 (m, 1 H), 1.72-1.59 (m, 2 H), 1.35-1.11 (m, 15 $\mathrm{H}), 0.96(\mathrm{~s}, 1 \mathrm{H}), 0.88(\mathrm{t}, J=6.6 \mathrm{~Hz}, 3 \mathrm{H}) ;{ }^{13} \mathrm{C} \mathrm{NMR}\left(100 \mathrm{MHz}, \mathrm{CDCl}_{3}\right) \delta$ 158.1, 130.7, 130.2, 114.0, $74.8,64.9,55.2,39.1,39.0,38.3,33.9,31.9,30.0,29.59,29.55,29.3,26.4,22.7,14.1$ (two aliphatic carbons are incidentally equivalent); IR (film) $3392 \mathrm{~cm}^{-1}$; MS (ESI): 348.2906 (348.2903 calculated for $\mathrm{C}_{22} \mathrm{H}_{37} \mathrm{NO}_{2}, \mathrm{M}+\mathrm{H}^{+}$).

( \pm -(2S,3S,5R)-2-(4-Trifluoromethylbenzyl)-3-hydroxy-5-nonylpyrrolidine (35). This compound was prepared on a $0.1 \mathrm{mmol}$ scale using a procedure analogous to that employed for the synthesis of 31. Substrate 23 (59 mg, $0.1 \mathrm{mmol})$ was transformed to the title compound to afford $31.5 \mathrm{mg}(82 \%)$ of a white solid, m.p. $45-47{ }^{\circ} \mathrm{C} .{ }^{1} \mathrm{H}$ NMR $\left(500 \mathrm{MHz}, \mathrm{CDCl}_{3}\right) \delta 7.53(\mathrm{~d}, J=8.2 \mathrm{~Hz}, 2 \mathrm{H}), 7.41(\mathrm{~d}, J=8.2$ Hz, $2 \mathrm{H}), 3.80-3.72$ (m, 1 H), 3.00-2.92 (m, $1 \mathrm{H}), 2.88$ (dd, J = 4.4, $13.2 \mathrm{~Hz}, 1 \mathrm{H}), 2.34$ (s, $3 \mathrm{H})$, 2.30-2.11 (m, 3 H), 2.03-1.90 (m, $1 \mathrm{H}), 1.78-1.67(\mathrm{~m}, 1 \mathrm{H}), 1.44(\mathrm{dd}, J=5.6,13.4 \mathrm{~Hz}, 1 \mathrm{H})$, 1.37-1.17 (m, $15 \mathrm{H}), 0.88(\mathrm{t}, J=6.8 \mathrm{~Hz}, 3 \mathrm{H}) ;{ }^{13} \mathrm{C}$ NMR $\left(125 \mathrm{MHz}, \mathrm{CDCl}_{3}\right) \delta 143.6,129.8,128.4(\mathrm{q}, J$ $=32.2 \mathrm{~Hz}), 125.2,124.3(\mathrm{q}, J=272.0 \mathrm{~Hz}), 73.3,70.3,65.7,39.3,38.5,34.9,33.6,31.9,29.9$, 29.61, 29.55, 29.3, 26.2, 22.7, 14.1; IR (film) $3401 \mathrm{~cm}^{-1}$; MS (ESI): 386.2671 (386.2671 calculated for $\mathrm{C}_{22} \mathrm{H}_{34} \mathrm{~F}_{3} \mathrm{NO}, \mathrm{M}+\mathrm{H}^{+}$).

( \pm )-(2S,3R,5R)-2-(4-Trifluoromethylbenzyl)-3-hydroxy-5-nonylpyrrolidine (36). This compound was prepared on a $0.1 \mathrm{mmol}$ scale using a procedure analogous to that employed for the synthesis of 31. Substrate $24(59 \mathrm{mg}, 0.1 \mathrm{mmol})$ was transformed to the title compound to afford $30.8 \mathrm{mg}(80 \%)$ of a white solid, m.p. $48-49{ }^{\circ} \mathrm{C} .{ }^{1} \mathrm{H}$ NMR $\left(400 \mathrm{MHz}, \mathrm{CDCl}_{3}\right) \delta 7.54(\mathrm{~d}, J=8.0 \mathrm{~Hz}, 2 \mathrm{H}), 7.37(\mathrm{~d}, J=8.0$ Hz, 2 H), 4.00-3.90 (m, 1 H), 3.00 (dd, J = 4.5, 13.5 Hz, 1 H), 2.75-2.62 (m, 1 H), 2.57-2.42 (m, 2 H), $2.32(\mathrm{~s}, 3 \mathrm{H}), 1.83-1.52(\mathrm{~m}, 3 \mathrm{H}), 1.48-1.06(\mathrm{~m}, 16 \mathrm{H}), 0.88(\mathrm{t}, J=6.2 \mathrm{~Hz}, 3 \mathrm{H}) ;{ }^{13} \mathrm{C} \mathrm{NMR}(100 \mathrm{MHz}$, 
$\left.\mathrm{CDCl}_{3}\right) \delta 143.3,129.7,128.5(\mathrm{q}, J=32.4 \mathrm{~Hz}), 125.2,124.3(\mathrm{q}, J=272.0 \mathrm{~Hz}), 76.7,74.5,64.7,39.6$, 39.3, 39.1, 33.9, 31.9, 30.0, 29.6, 29.5, 29.3, 26.3, 22.7, 14.1; IR (film) 3369, 2927, 1326, 1126, 843 $\mathrm{cm}^{-1}$; MS (ESI): 386.2673 (386.2671 calculated for $\mathrm{C}_{22} \mathrm{H}_{34} \mathrm{~F}_{3} \mathrm{NO}, \mathrm{M}+\mathrm{H}^{+}$).

Asymmetric aldol reaction of 2-undecanone with acrolein. A flame-dried flask was cooled under a steam of nitrogen and charged with (-)-DIPCl (514 mg, $1.6 \mathrm{mmol})$, and $\mathrm{CH}_{2} \mathrm{Cl}_{2}(6 \mathrm{~mL})$. A thermocouple was inserted to the solution through a rubber septum and the mixture was cooled to an internal temperature of $-78{ }^{\circ} \mathrm{C}$. Triethylamine $(280 \mu \mathrm{L}, 2 \mathrm{mmol})$ was added followed by a solution of 2-undecanone $(207 \mu \mathrm{L}, 1 \mathrm{mmol})$ in $\mathrm{CH}_{2} \mathrm{Cl}_{2}(1 \mathrm{~mL})$. The resulting was mixture was stirred at $-78^{\circ} \mathrm{C}$ for $1.5 \mathrm{~h}$, then a solution of acrolein $(100 \mu \mathrm{L}, 1.5 \mathrm{mmol})$ in $\mathrm{CH}_{2} \mathrm{Cl}_{2}(3 \mathrm{~mL})$ was added slowly dropwise and the reaction mixture was stirred at $-78{ }^{\circ} \mathrm{C}$ for an additional $2.5 \mathrm{~h}$ then warmed to $0{ }^{\circ} \mathrm{C}$ with stirring for 1h. The disappearance of starting material was verified by TLC analysis. The reaction mixture was diluted with $\mathrm{Et}_{2} \mathrm{O}$ and quenched with a buffer solution $(10 \mathrm{~mL}, \mathrm{pH}=7)$. The layers were separated and the aqueous phase was extracted with $\mathrm{Et}_{2} \mathrm{O}(3 \mathrm{x} 15 \mathrm{~mL})$. The organic extracts were combined and concentrated in vacuo in a flask equipped with a magnetic stir bar. The crude oil obtained was diluted with $\mathrm{MeOH}(7 \mathrm{~mL})$, a buffer solution $(1 \mathrm{~mL}, \mathrm{pH}=7)$ and the mixture was cooled to $0{ }^{\circ} \mathrm{C}$. An aqueous solution of $\mathrm{H}_{2} \mathrm{O}_{2}(2 \mathrm{~mL}, 30 \mathrm{wt}$. \%) was slowly added and the mixture was stirred at $\mathrm{rt}$ for $3 \mathrm{~h}$. The reaction was then diluted with water $(10 \mathrm{~mL})$ and extracted with $\mathrm{CH}_{2} \mathrm{Cl}_{2}(3 \times 15 \mathrm{~mL})$. The extracts were washed with saturated aqueous $\mathrm{NaHCO}_{3}$ solution and $\mathrm{FeSO}_{4}$ saturated aqueous solution (3x, until the green color persisted). The organic phase was dried over anhydrous $\mathrm{Na}_{2} \mathrm{SO}_{4}$, filtered and concentrated in vacuo before being purified using $20 \% \mathrm{Et}_{2} \mathrm{O} / \mathrm{Hexanes}$ as the eluent to afford $169.5 \mathrm{mg}(78 \%)$ of nonracemic 7 as a colorless oil. This material was characterized by ${ }^{1} \mathrm{H}$ NMR analysis prior to derivatization to assay enantiopurity; NMR data were identical to those given above.

Benzoylation of nonracemic 7. A flame-dried flask was cooled under a steam of nitrogen and charged with nonracemic $7(165 \mathrm{mg}, 0.73 \mathrm{mmol})$, and pyridine $(7 \mathrm{~mL})$. The mixture was cooled to $0{ }^{\circ} \mathrm{C}$ and benzoyl chloride $(340 \mu \mathrm{L}, 2.92 \mathrm{mmol})$ was added dropwise via syringe. The resulting mixture was stirred at $0{ }^{\circ} \mathrm{C}$ until the starting material was consumed as judged by TLC analysis (ca. 1h). The reaction mixture was then diluted with water $(10 \mathrm{~mL})$ and ethyl acetate $(15 \mathrm{~mL})$. The layers were separated and the aqueous phase was extracted with ethyl acetate $(3 \times 10 \mathrm{~mL})$. The combined organic extracts were dried over anhydrous $\mathrm{Na}_{2} \mathrm{SO}_{4}$, filtered and concentrated in vacuo before being purified by flash chromatography using 5\% ethyl acetate/hexanes as the eluent to afford $174.8 \mathrm{mg}(73 \%)$ of O- 
benzoyl-7 as a colorless oil. This optical purity of this material was judged to be $48 \%$ ee by HPLC analysis using the method described below. ${ }^{1} \mathrm{H} \mathrm{NMR}\left(400 \mathrm{MHz}, \mathrm{CDCl}_{3}\right) \delta 8.02(\mathrm{~d}, J=7.0 \mathrm{~Hz}, 2 \mathrm{H})$, $7.56(\mathrm{t}, J=7.2 \mathrm{~Hz}, 1 \mathrm{H}), 7.43(\mathrm{t}, J=7.8 \mathrm{~Hz}, 2 \mathrm{H}), 6.00-5.90(\mathrm{~m}, 2 \mathrm{H}), 5.41-5.34(\mathrm{~m}, 1 \mathrm{H}), 5.26-5.20$ $(\mathrm{m}, 1 \mathrm{H}), 3.02-2.94(\mathrm{~m}, 1 \mathrm{H}), 2.82-2.74(\mathrm{~m}, 1 \mathrm{H}), 2.45(\mathrm{t}, J=7.4 \mathrm{~Hz}, 2 \mathrm{H}), 1.62-1.51(\mathrm{~m}, 2 \mathrm{H})$, $1.33-1.18(\mathrm{~m}, 12 \mathrm{H}), 0.87(\mathrm{t}, J=6.8 \mathrm{~Hz}, 3 \mathrm{H}) ;{ }^{13} \mathrm{C} \mathrm{NMR}\left(100 \mathrm{MHz}, \mathrm{CDCl}_{3}\right) \delta 207.2,165.4,135.4$, 133.0, 130.1, 129.6, 128.4, 117.1, 71.1, 47.0, 43.5, 31.8, 29.38, 29.36, 29.2, 29.1, 23.6, 22.6, 14.1.

\section{Assay for determination of enantiomeric excess of nonracemic 7 prepared through asymmetric} aldol reaction of undecanone with acrolein: The $O$-benzoyl derivative of $7(20 \mathrm{mg})$ was dissolved in hexanes $(2 \mathrm{~mL})$ and injected in an HPLC apparatus equipped with chiral column $(R, R)$ WHELK-O 1 (Regis Tech.). The system permitting separation of enantiomers (RT = $8.200 \mathrm{~min}$ and $8.850 \mathrm{~min}$ ) was found to be $5 \%$ isopropanol/hexanes, flow rate $=1 \mathrm{~mL} / \mathrm{min}$ at wavelengths $220 \mathrm{~nm}$ and $254 \mathrm{~nm}$. The ee then measured was $48 \%$.

\section{References}

1 Huang, P. -Q.; Wu, T. -J.; Ruan, Y. -P. Org. Lett. 2003, 5, 4341.

2 Bach, T.; Brummerhop, H.; Harms, K. Chem. Eur. J. 2000, 6, 3838 and references cited therein.

3 (a) M.; Okue, Watanabe, H.; Kasahara, K.; Yoshida, M.; Horinouchi, S.; Kitahara, T. Biosci. Biotechnol. Biochem. 2002, 66, 1093. (b) Deng, W.; Overman, L. E. J. Am. Chem. Soc. 1994, 116, 11241.

4 Yamamoto, K.; Ogura, H.; Jukuta, J. -i.; Inoue, H.; Hamada, K.; Sugiyama, Y.; Yamada, S. J. Org. Chem. 1988, 63, 4449.

5 (a) Johnson, J. H.; Phillipson, D. W.; Kahle, A. D.; J. Antibiot. 1989, 42, 1184. (b) Schwartz, R. E.; Liesch, J.; Hensens, O.; Zitano, L.; Honeycutt, S.; Garrity, G.; Fromtling, R. A. J. Antibiot. 1988, 41, 1774. 